\section{KU ŨNamonu Eğitim Dergisi Kastamonu Education Journal}

Temmuz 2019 Cilt:27 Sayı:4

kefdergi.kastamonu.edu.tr
Başvuru Tarihi/Received: 16.07 .2018

Kabul Tarihi/Accepted: 06.09.2018 DOI: 10.24106/kefdergi.3229

\title{
Sınıf Öğretmeni Adaylarının Okuma ve Matematik Güçlüklerine İlişkin Pedagojik Farkındalıklarının ve Öğretimsel Bakış Açılarının Belirlenmesi ${ }^{1}$
}

\section{Determination of Pre-service Primary School Teachers' Pedagogical Awareness of Reading and Math Difficulties and Instructional Perspectives}

\author{
Hayriye Gül KURUYER², Ahmet ÇAKIROĞLU³, Gökhan ÖZSOY4
}

\begin{abstract}
Öz
Bu araştırmada, sınıf öğretmeni adaylarının okuma ve matematik güçlüklerine ilişkin pedagojik farkındalıklarının ve öğretimsel bakış açılarının belirlenmesi amaçlanmıştı. Araştırma, iç içe geçmiş çoklu durum deseniyle yürütülmüştür. Araştırmanın çalışma grubunu, Sınıf Öğretmenliği Lisans Programında üçüncü ve dördüncü sınıfa devam etmekte olan 73 öğretmen adayı oluşturmuştur. Araştırma sonucunda öğretmen adaylarının okuma güçlügüne ve matematik güçlüğüne ilişkin bir farkındalığa sahip olduklarını söylemek mümkündür. Ancak öğretmen adaylarının yanıtları incelendiğinde okuma ve matematik güçlüklerine ilişkin bilgi eksiklerinin olduğu ve yanılgılara sahip oldukları görülmüştür. Bununla birlikte okuma ve matematik güçlüklerinin nasıl tespit edileceği ve nasıl giderileceğine ilişkin bir öngörüye sahip olmadıkları belirlenmiştir.
\end{abstract}

Anahtar Kelimeler: okuma güçlüğü, matematik güçlüğü, sınıf öğretmeni, öğretmen adayı

\section{Abstract}

The purpose of the current study is to determine pre-service primary school teachers' pedagogical awareness of reading and math difficulties and pedagogical perspectivess. The study was conducted according to the embedded multiple-case design. The study group for the current research comprised 73 third- and fourth year pre-service primary school teachers. Considering the findings of the current study, it can be argued that pre-service teachers have an awareness of reading and math difficulties. However, when pre-service teachers' responses were examined, some shortcomings and fallacies in their knowledge about reading and math difficulties were discovered. In addition, it was also found that they did not have knowledge about how to detect and eliminate reading and math difficulties.

Keywords: reading difficulties, math difficulties, primary school teacher, teacher candidate

1.Bu makalenin özeti 4th. International Conference on Education da sunulmuştur.

2. Ordu Üniverstesi, Ordu, Türkiye; https://orcid.org/0000-0001-9017-8432

3. Aksaray Üniversitesi,Aksaray, Türkiye; https://orcid.org/0000-0003-0833-9597

4. Ordu Üniversitesi, Ordu, Türkiye; https://orcid.org/0000-0002-1250-624X

Atıf / Citation: Kuruyer, H. G., Çakıroğlu, A., \& Özsoy, G. (2019). Sını öğretmeni adaylarının okuma ve matematik güçlüklerine ilişkin pedagojik farkındalıklarının ve öğretimsel bakış açılarının belirlenmesi. Kastamonu Education Journal, 27(4), 1659-1678. doi:10.24106/kefdergi.3229 


\section{Extended Abstract}

It is possible to say that primary school teachers play a critical role in the early identification of students' reading and math difficulties. However, it can be argued that primary school teachers have both a lack of knowledge and conceptual and phenomenological fallacies that make it challenging to identify these difficulties. Individuals suffering from reading and math difficulties are not able to receive accurate guidance and assistance from their families, especially outside their school. These students have to be content with the activities conducted by the teacher directed toward developing reading and math skills at school. In general, it is possible to say that even if the difficulties experienced by students have been identified, they cannot obtain sufficient support to overcome these issues. From this point of view, the programs that train primary school teachers should aim to equip them with knowledge and awareness of the difficulties in reading and math that can be encountered by students and the experience needed to deal with them. However, when the course contents in the Primary Teacher Education programs in Turkey (YOK, 1998) are examined, it can be seen that there are no theoretical and applied courses aiming to raise students' awareness of difficulties with reading and math. This can be interpreted as an indication that pre-service science teachers cannot acquire sufficient knowledge and skills related to math difficulties.

When the existing academic research and applications in the world are considered, it can be said that the amount of research and applications concerning how to address issues with reading and math in Turkey is inadequate (Hacısalioğlu-Karadeniz, 2013; Akyol and YIldiz, 2013). In Turkey, it is generally accepted that such difficulties are common problems among primary school students and it is known that there are no teachers specializing in this field in primary schools (Akyol, Çakıroğlu and Kuruyer, 2014; Akyol and Yıldız, 2013; Altun, Ekiz and Odabaşı, 2011; Bintaş, 2007; Sezer and Akın, 2011). This current situation shows the importance of primary teachers in dealing with students' difficulties with reading and math and the necessity of building the training offered to pre-service primary school teachers on this issue.

"How pre-service teachers perceive and judge themselves in terms of knowledge, skills and experiences is of great importance for them to provide effective instructional service and to deal with the pedagogical difficulties they will encounter throughout their professional career." (Özdemir, 2008: p. 277). In this regard, the purpose of the current study is to determine pre-service primary school teachers' pedagogical awareness and educational perspective on reading and math difficulties.

Difficulties with reading and math are particularly evident in the first grades of primary school. As primary teachers are those who teach first-fourth graders in primary education, it is supposed that they will require pedagogical awareness and instructional knowledge and skills in relation to these student issues. The current research is limited to pre-service primary school teachers and the determination of their pedagogical awareness and instructional perspective on difficulties with reading and math. The current study is believed to be important in making a contribution to the development of the existing primary school teacher educational curriculums by revealing the pre-service primary school teachers' pedagogical awareness and instructional perspective on this issue. Moreover, the findings to be obtained in the current study are believed to make some important contributions to the definition of the role of primary school teachers in assessing issues with reading and math, the formation of an instructional tasks framework and the determination of the professional content competencies in the literature. To this end, the current research seeks to answer the following questions:

- What is pre-service primary school teachers' pedagogical awareness of reading and math difficulties?

- What are pre-service primary school teachers' instructional perspectives on reading and math difficulties?

Method: The purpose of the current study is to determine pre-service primary school teachers' pedagogical awareness of reading and math difficulties and instructional perspectives. The current study employed an embedded multiple-case study design.

Study Group: The study was conducted with the participation of 73 third-and fourth-year pre-service primary school teachers. Third- and fourth-year students were selected as they have already completed third-year courses such as First Reading and Writing Instruction, Turkish Language Teaching and Mathematics Teaching I and II.

\section{Data Collection}

Data for the current study were collected in three stages. In the first stage, a semi-structured interview that included eight questions related to difficulties with reading and math was administered. In the second stage, narratives of students experiencing issues with reading and math were distributed to pre-service teachers, who were asked to evaluate these narratives in terms of the difficulties experienced by the students. In the third stage, pre-service teachers were provided with video-recordings of students experiencing reading and math difficulties and were then asked to determine the methods that needed to be used to deal with these difficulties.

Data Analysis: The collected data were evaluated using a descriptive analysis method. The stages that were followed in the analysis of the collected data are given below:

- Determination of themes

- Transcription of data

- Organization of data according to themes 


\section{- Analysis and interpretation of data}

- Pre-service teachers' responses to the questions related to reading and math difficulties are presented according to the themes of pedagogical awareness and instructional perspectives.

Results: In light of the research findings and their interpretations, it can be said that the pre-service primary school teachers have both general and relative awareness of reading and math difficulties. However, when the pre-service teachers' responses were examined, it was found that they to some extent lack factual and phenomenological knowledge as well as having some misconceptions. In addition, they do not know how to identify students' difficulties in reading and math or how to deal with them.

When the findings of the current study are considered, the pre-service teachers can be said to have some difficulties in explaining the concepts related to issues with reading and math. From the evaluations made by the pre-service teachers about the presented cases of students experiencing reading and math issues, it became evident that they do not know the characteristics of reading and math difficulties, related concepts, diagnosis criteria and the approaches that can be followed to intervene with students experiencing such difficulties. This might be because of the inadequate emphasis placed on instruction concerning difficulties with reading and math and instructional intervention approaches within the courses of First Reading and Writing Teaching, Turkish Teaching, Math Teaching I and II and Special Education in the undergraduate program (YÖK, 1998). In addition, there is no particular course that specifically focusses on difficulties with reading and math.

There are two criteria used in the identification of reading and math difficulties and in the application of intervention programs in the classroom setting. First are the observations made by primary school teachers, which can serve as an important source of information for the identification of students with these difficulties (McLoughlin and Lewis, 2004). The second is that primary school teachers play a primary role in the development and application of intervention programs on the basis of the results of identification efforts (Duffy and Atkinson, 2001; Westwood, 2000). Therefore, it seems important for pre-service primary school teachers to receive special instruction that will prepare them to diagnose and deal with students' difficulties in these areas (Stuart, 2000; Westwood, 2008).

When the research conducted in Turkey on reading and math difficulties is examined, it is seen that while they differ to some extent from the current study and its results, there are several studies focusing on the characteristics of reading and math difficulties (Olkun, Akkurt-Denizli and Göçer-Şahin, 2015; Tatar and Dikici, 2008), the determination of the characteristics of students experiencing these difficulties (Turgut, 2008), applications directed at the elimination of these difficulties (Akyol, Çakıroğlu and Kuruyer, 2014; Dündar and Akyol, 2014; Baydık, 2011; Bintaş, 2007) and problems encountered by primary school teachers and pre-service primary school teachers (Altun, Ekiz and Odabaşı, 2011; Çakıroğlu and Kuruyer, 2012; Hacısalioğlu-Karadeniz, 2013; Sezer and Akın, 2011; Yurdakal, 2014). If further research attaches greater importance to the identification of the students experiencing reading and math difficulties and standard procedures to be followed to cope with them, as well as to the perspective and professional competences that should be possessed by primary school teachers and pre-service primary school teachers in this process, it may yield more useful findings.

It can be said that within our education system, more importance should be attached to the identification of the students with these difficulties, the development of a new primary school teacher viewpoint and the restructuring of the system according to this new viewpoint. This is necessary because the lack of a standard application for the identification of students with reading and math difficulties and intervention with these difficulties makes the individual competences and pedagogical knowledge of primary school teachers in relation to these issues much more important. The number of primary school teachers participating in the current study is 73 , which should be considered a limitation of the study. Future research could investigate the pedagogical awareness and instructional perspective of primary school teachers with different characteristics and in larger samples. It is considered to be important for future research to focus on the opinions and experiences of the families and primary school teachers of the students with reading and math difficulties and those of other stakeholders. Moreover, through the mixed research approach, future research can be conducted to support primary school teachers' pedagogical awareness and instructional perspective on difficulties with reading and math with both qualitative and quantitative findings. It seems to be of particular importance to renew the primary school teacher education undergraduate programs, incorporate courses with a direct focus on these difficulties and enhance the content of the related courses in the current programs. In addition, identification and intervention systems for reading and math difficulties should be developed in primary schools, field experts should be appointed as consultants to schools, pre-service primary school teachers should be provided with experiences about identification and intervention programs and opportunities to work with field experts. Further research should focus on primary school teachers' pedagogical awareness and instructional perspective on students' difficulties with reading and math. 


\section{Giriş}

Öğrencilere okuma becerileri kazandırılmasının en önemli amacı, onları 'nitelikli' bir okuryazar olarak yetiştirmektir. Bireyin nitelikli okuryazar olması, okuduğunu anlaması, anladığını da içinde yaşadığı ortamı geliştirmek amacıyla çeşitli yönlerden etkin olarak kullanmasıdır (Yıldırım, 2010). Bu bakış açısıyla, bireylere okuma becerisinin kazandırmanın temel amacı, bireyin kişiliğini geliştirmesi ve toplumla sağlıklı ilişkiler kurması olduğu söylenebilir (Glenberg, 2011; Güneş, 2003). Matematik becerilerinin kazandırılmasında en önemli nokta ise, derin ve uyarlanabilir matematik içerik bilgisine sahip matematik okuryazarı ve gerçek hayat problemlerini çözebilen bireyler yetiştirmektir (Van de Walle, Karp ve Bay-Williams, 2013). Öğrencilerin okuma ve matematik becerilerini kazanmaları ve geliștirmeleri özellikle ilkokul düzeyinde gerçekleşmektedir (Altun, 2014; Güneş, 2013; Temur, 2006). Illkokul düzeyinde okuma ve matematik becerilerinden herhangi birinin tam olarak kazanılamamış olması, sınıf düzeyi yükseldikçe bireyin okumayla ve matematikle ilgili yaşadığı sorunların artmasına, okulda ve günlük hayatında güçlükler yaşamasına sebep olmaktadır. Bazı öğrencilerin, zekâ kapasiteleri normal ya da normale yakın olmasına rağmen akranlarıyla benzer performans gösteremedikleri, özel öğrenme güçlüğü yaşadıkları bilinmektedir (Deniz, Yorgancı ve Özyeşil, 2009). Özel öğrenme güçlüğü, bilgiyi almak ile ilgili yaşanan çocuğun yaşı ve doğal zekâsı ile tutarlı olmayan ve kültür ya da eğitim imkânlarının zayıflığı gibi çevresel faktörlerle açıklanamayan bir problemdir (Morrison, 2016).

Özel öğrenme güçlüğü özellikle çocukluk çağında görülen bir veya birden fazla akademik beceri alanında gözlenen işlevsel bozukluklardır (Silver vd., 2008). Bir başka deyişle; özel öğrenme güçlüğü olan öğrenciler, okuma, anlama ve dil kullanımında, dinleme, düşünme veya matematik alanlarında düşük başarı gösteren ve bu alanlarda güçlükler yaşayan öğrencilerdir (Bender, 2012; Santrock, 2016). Özel öğrenme güçlüklü öğrenciler öğrenme konusunda güçlük yaşarlar ve genellikle okulda başarılı olmalarına yardımcı olmak için ek desteğe ihtiyaç duyarlar (Kirk, Gallagher ve Coleman, 2017, s. 171). Mental Bozuklukların Tanısal ve Sayımsal El Kitabında [Diagnostic and Statistical Manual of Mental Disorders-DSM-V] belirtildiği üzere temel akademik becerilerin yanı sıra özel öğrenme güçlüğü olan öğrencilerin temel sosyal ve bilişsel beceri alanlarında da güçlük yaşadığı gözlenmektedir. Ayrıca, DSM V, özel öğrenme güçlüğünü nörogelişimsel bozukluklar başlığı altında ele almış ve okumada bozukluk, yazılı anlatımda bozukluk ve matematikte bozukluk olarak sınıflandırmıştır (DSM-V, 2013). Bu sınıflamaya ek olarak, bozukluklar hafif, orta ve ağır olmak üzere üç farklı seviyeye ayrılmıştr. Okumada bozukluk, matematikte bozukluk ve yazılı anlatımda bozukluk tek başına görülebileceği gibi, matematik bozukluğu, yazılı anlatım bozukluğu ve okuma bozukluğu birlikte de görülebilir.

\section{Okuma Güçlükleri}

“Okullarda öğrenme-öğretme sürecinde kullanılan öğrenme araçlarının büyük bir kısmının dile dayalı kaynaklar olması, okuduğunu anlamanın önemini daha da artırmaktadır" (Akyol ve Yıldız, 2013, s.1). Bu bakış açısıyla okuma, akademik başarı için temel bir beceri (Calhoon, 2005) olmakla birlikte, çıkarımda bulunma, doğru seslendirme ve anlamadan oluşan interaktif bir süreçtir (Kamhi ve Catts, 2008). Okumanın karmaşık yapısının yanı sıra bu süreçte bilgi, motivasyon, hafiza, kavrayış, algı ve dikkat gibi bireysel farklılıklar da karşımıza çıkmaktadır. Örneğin, "Suki'ye kimonoyu büyükannesi vermişti. Onu ilk kez giydiğinde, büyükannesi Suki'yi bir sokak festivaline götürmüştü; birlikte kaseler dolusu kaygan ve soğuk makarnayı hüpletmiş, tatıı barbunya soslu kıttr bir buzlaş külahını paylaşmışlardı.... ." (Uegaki ve Jorisch, 2016) şeklinde kısa bir metni okurken çocuk, metni okumaya odaklanmalı, kelimeleri tanımalı, metni doğru seslendirmeli, metne yönelik motivasyona sahip olmalı ve anlamı yapılandırmalıdır. Bu durumlardan birinin eksik olması halinde okuduğunu anlamanın gerçek anlamıyla gerçekleşmediğini söylememiz mümkündür. Bazen söz konusu eksiklikler öğrencilerin kendi bireysel çabalarıyla veya öğretmeninin küçük müdahaleleriyle çözülebilmektedir. Ancak bazı durumlarda bu eksiklikler fark edilememekte ve söz konusu eksikliklerin giderilebilmesi için profesyonel ve sistematik bir müdahale programına intiyaç duyulmaktadır. Bu eksikliklerin varlığını okuma güçlüğü kavramıyla açıklamak mümkündür.

Okuma güçlüğü olan bireylerin okuma performanslarının, yaş, zekâ düzeyi ve aldıkları eğitim göz önünde bulundurulduğunda akranlarına göre beklenilenin önemli derecede altında olduğu görülmektedir (İşeri ve Akın-Sarı, 2011). Okuma güçlüğü, sessiz okurken anlamada ve hızda zorluk, sesli okurken doğruluk ile zorluk ve hecelemeye çalışırken heceleme ile ilgili zorluk şeklinde karşımıza çıkabilmektedir (Morrison, 2016). Okuma güçlüğü olan öğrenciler okudukları metindeki anlam bütünlüğünü algılama, okurken strateji kullanma, okuduklarını önceki bilgileri ile ilişkilendirme gibi becerilerden yoksundurlar ve anlamada güçlükler yaşamaktadırlar (Bonds ve Bonds, 1992; Moddy, Kennedy ve Brady, 1997; Jitendra, Hoppes ve Xin, 2000). Okuma güçlükleri olan öğrencilerin metnin yapısını tanımlamada, önemli detayları hattrlamada ve ana fikri bulmada etkili olamadıkları bilinmektedir (Gersten, Fuchs, Williams ve Baker, 2001). Okuma güçlüğü olan öğrencilerin yanlış okuma, harf-hece atlama, harf-hece ekleme, farklı sözcük okuma, okunan kelimenin bir kısmını tekrarlama gibi hataları yapma oranının daha fazla olduğunu ve okuma güçlüğü olan öğrencilerin 
okuma akıcılığının doğruluk, otomatiklik ve prozodi boyutlarının tümünde sorun yaşadıklarını söylemek mümkündür. Bununla birlikte bu öğrenciler dikkat, bellek, öğrenme, görsel-mekânsal algılama sorunları, anlambilim, sözdizim ve biçim bilim sorunları da yaşamaktadır (Baydık, 2014; Kuruyer, 2014). Okuma güçlüğü olan öğrenciler özellikle sınıfta kalmanın olmadığı ilkokulda sınıf düzeyinde ilerleseler de, sınıf düzeyine uygun okumayı gerçekleştiremedikleri için bütün öğrenme hayatları boyunca kaygı, depresyon, endişe gibi farklı sorunlar yaşamaktadırlar (Akyol, Çakıroğlu ve Kuruyer, 2014). Özellikle bu öğrenciler okul hayatları boyunca 'başarısız' olarak etiketlenmektedirler. Bu etiketle birlikte sahip olduğu güçlüğün giderilmesine yönelik bir yardım alamamakta ve sınıf ortamına uyum sağlayamamaktadır (Bender, 2012). Çünkü okuma ve okuduğunu anlamanın öğrenme için okuma kavramına evrildiği düşünüldüğünde çoğu öğrenme becerilerini kazanma konusunda okuma ve okuduğunu anlama öncül bir beceridir. Bu beceri de yaşanan güçlükler, öğrenmeyi ve akademik performansı dolayısıyla çocuğun okul hayatını olumsuz yönde etkilemektedir.

Okuma görevlerine katılımda endişe duyan, isteksiz olan, okuma akıcılığının doğruluk, otomatiklik ve prozodi boyutlarının tümünde sorun yaşayan öğrencilerin okuma güçlüğü riski taşıdığı düşünülebilir. Okuma güçlüğü riski taşıdığı düşülen öğrencinin güçlüklerinin tanılanması ve tespit edilmesi gerekir. Okuma güçlüğü tespit edilmesinde izlenecek yolu ses farkındalığına, kelime tanıma-ayırt etme, okuduğunu anlama beceri ve performansına yönelik yapılan ayrıntlı tanılama, bireyin zekâ geriliği yaşamadığına ilişkin uzman görüşünün alınması ve dikkat, bellek, algı problemlerinin dışlanması şeklinde tanımlamak mümkündür (Westwood, 2008). Okuma güçlüğünün tespit edilmesinde başlangıç noktasının öğretmenlerin bu öğrencilerle ilgili görüşleri olduğunu söylemek mümkündür. Okuma güçlüklerini tanılama sürecinde öğretmenlerin, öncelikle öğrencilerinin okuma becerilerini değerlendirmeleri gerekir. Okuma becerileri; standart olmayan testler aracılığıyla yapılan informal değerlendirme ve standart testler aracılığıyla yapılan formal değerlendirme olmak üzere iki şekilde değerlendirilir.

Okuma becerilerinin informal değerlendirilmesi öğretmenlerin kullanımı için uygun bir ölçme değerlendirme sürecidir. Bu kapsamda okuma düzeylerini, okuma hatalarını, okuma akıcılığını ve okuduğunu anlama sorularına verilen yanıtları değerlendirmeleri gerekir (Baydık, 2014). Gözlem, görüşme, okuma kontrol listeleri, ölçüt bağımlı testler, öz değerlendirme, ürün dosyaları okuma becerisinin informal değerlendirilmesine olanak sağlar (Karasu, Girgin ve Uzuner, 2011). Okuma güçlüğü olan öğrencilerin yaşadıkları güçlüklere ilişkin detaylı tanılamanın yapılması, öğrenme güçlüklerinin giderilmesine yönelik öğrenme ortamlarının oluşturulması için ilk adım olarak düşünülmelidir (Kuruyer, 2014). Öğretmen informal değerlendirme yaparak, öğrencinin okuma düzeyini ve ne tür güçlükler yaşadığını belirleyerek öğrenci gereksinimlerini ortaya koyabilir. Gereksinimler ortaya konulduktan sonra öğretmenin söz konusu gereksinimleri karşılaması ve güçlükleri ortadan kaldırmak için okuma becerilerini geliştirmeye yönelik müdahale uygulamaları yapmaları gereklidir. Öğretmen bu kapsamda, sesbilgisel farkındalık, kelime tanıma, kelime ayırt etme, okuduğunu anlama, akıcı okuma becerilerini iyileştirmeye ve geliştirmeye yönelik etkinlikler yapabileceği gibi, strateji öğretimi ve okuma güçlüklerinin giderilmesine yönelik geliştirilmiş bilimsel müdahale programlarını da kullanabilir (Balıkçı, 2017). Alanyazında okuma güçlüğünün giderilmesine yönelik birçok uygulama ve modelin önerildiği görülmektedir (Akyol, 2005; Bender, 2012; Kuruyer, 2014). Kelime tanıma ve okuma becerisini geliştirmeye yönelik kullanılan strateji öğretimi (Antoniou ve Souvignier, 2007; Reid, Lienemann ve Hagaman, 2013), zenginleştirilmiş okuma programı (Kuruyer, 2014), akranla okuma (Woolley, 2007), okuyucu tiyatroları, eşli okuma (Dündar ve Akyol, 2014; Kuruyer, 2014) bu uygulamalardan sadece birkaçıdır. Modeller ve müdahale programlarının uygulamasında temel kural güçlüğün giderilmesine yönelik olmasıdır.

\section{Matematik Güçlükleri}

Matematik eğitimi bireylere, dünyayı ve sosyal etkileşimleri anlamaya yardımcı olacak geniş bir bilgi ve beceri donanımı sağlar. Matematik eğitiminin başlıca amacı kişiyi, aritmetik, cebir ve geometrinin temel bilgileriyle donatmanın yanı sıra, düşünmeye yöneltmek; akıl yürütmelerinde ulaştğı sonuçlarda tutarlı olma duyarlılığına ulaştırmaktır (Yıldırım, 2000). Matematik eğitimi bireylere, günlük hayatta karşılaşılan problemleri çözmek için matematiksel düşünme tarzını geliştirebilecekleri, aritmetik becerileri kazanabilecekleri bir dil ve sistematik kazandırır (ilkokul ve Ortaokul Matematik Dersi Programı, 2018). Matematik kendine özgü dile, sistematiğe ve içeriğe sahip bir alandır. Örneğin;

\section{"Sevgili Yavrum,}

Bu evde garip bir çamaşır makinesi var. Geçen gün içine dört gömlek koydum, çalıştırmak için duvardaki zinciri çektiğimden beri bir daha o gömlekleri görmedim. Geçen hafta sadece 2 kez yağmur yağdı. ilki üç gün sürdü, ikincisi ise dört gün. Benden istediğin yeleği postaya verdim. Ancak halan, o koca düğmelerle paketin çok ağır olacağını söyledi. O yüzden düğmeleri kopartıp yeleğin cebine koyduk. Orada bulabilirsin.

Bu mektupta mantiğa uymayan kaç durum vardır?” (Bilim ve Sanat Merkezleri Öğrenci Seçme Sınavı, 2015, 4. Sinıf) 
Yukarıdaki problemi okurken çocuk, problemi anlamaya odaklanmalı, plan yapmalı, çözüm için uygun strateji seçmeli, seçtiği stratejiyi uygulayabilmeli, günlük hayatla ilişkiler kurabilmeli, akıl yürütme ve iletişim becerilerini kullanabilmeli ve matematiğe karşı motivasyona sahip olmalıdır. Bu durumlardan birinin eksik olması matematik becerilerinin etkili kullanımını olumsuz etkileyecektir. Bazen matematik becerilerinin etkili kullanılamaması sorunu öğretmenin yönlendirmesi veya öğrencinin bireysel çabalarıyla ortadan kalkmaktadır. Ancak bazı durumlarda bu sorun daha kapsamlı bir probleme işaret etmektedir. Matematik güçlüğü, sayı ve aritmetik bilgisinin kazanımını engelleyen bir öğrenme güçlüğüdür (Piazza, vd., 2010). Matematik güçlüğü çocuğun yaşı ve zekâsı göz önünde bulundurulduğunda akademik başarısını ve günlük hayatını olumsuz etkileyen başarı-yetenek tutarsızlığı olarak tanımlamaktadır (Butterworth, 2005; Landerl, Bevan ve Butterworth, 2004). Matematik güçlüğü yaşayan öğrencilerin derslerde yaşadıkları sorunlar, öğrencinin derse kathlımına engel teşkil etmektedir. Matematiksel bilgi ve becerilerin diğer disiplinlerle ilişkisi düşünüldüğünde; matematik öğrenmede sınırlı ilerlemenin çocuğun akademik başarısını olumsuz yönde etkileyeceği öngörülebilir.

Matematik konuları ve bireysel özellikler matematiksel öğrenmeleri etkileyen iki temel unsurdur (Jonassen ve Grabowski, 2007). Özellikle ilkokul matematik programında yer alan konular düşünüldüğünde bu yaş çocuklarının öğrenmede zorlanacakları kavramların olmadığını söylemek mümkündür (Baykul, 2009). Bu bakış açısıyla matematik öğrenmedeki zorlukları, öğrencilerin yaşadığı dikkat, motivasyon, görsel algı ve hafiza sorunlarıyla, bireysel farklılıklar ile öğretimsel eksiklikler olarak açıklamak mümkündür. Matematik güçlüğü olan öğrencilerin; özellikle sayma ve hesaplama ile ilgili becerileri kazanmada zorlandıkları, buna bağlı olarak aritmetik işlem yapma ve hatılamada sorun yaşadıkları görülmektedir (Olkun, Akkurt-Denizli ve Göçer-Şahin, 2015). Matematik güçlüğü yaşayan öğrenciler temel sayı kavramını anlamada, sayıların sezgisel olarak kavranmasında, sayı gerçeklerini ve kurallarını ve işlemlerini anlamada zorluk yaşamaktadırlar (Tuğrul-Kalaç, 2015). Matematik güçlüğü yaşayan öğrenciler sayıları doğru okuyamama, basit toplama ve çıkarma işlemlerini gerçekleştirememe, aritmetik terimler ve sembolleri kavrayamama, matematik kurallarını ezberleyememe ve uzamsal yapıları anlayamama gibi sorunlar yaşarlar (Özkut, 2011). Bir başka deyişle matematik güçlüğü yaşayan öğrencilerin, basamak değeri, zaman ve nicelik gibi matematiksel kavramları algılamada, matematiksel bilgileri akılda tutmada, sayıları ve problemleri organize etmede zorluklar yaşadıkları görülmektedir (National Joint Committee on Learning Disabilities, 2000). Bu güçlük alanları homojen bir yapıda ve her öğrencide aynı güçlük düzeyinde de görülmemektedir.

Matematik güçlüklerinin tespit edilmesinde izlenecek yolu; matematiksel işlemleri yapmada uzmanlaşmanın akranlarına göre geciktiğinin gözlenmesi, temel matematik becerilerinin ve performansının ayrıntılı olarak değerlendirilmesi, bireyin zekâ geriliği yaşamadığına ilişkin uzman görüşünün alınması, dikkat, bellek, algı problemlerinin dışlanması şeklinde açıklamak mümkündür (Bender, 2012). Ayrıca matematik güçlüğünü tanılamada üç farklı yaklaşımdan söz etmek mümkündür. Bu yaklaşımlar çocuğun, (1) genel zekâ seviyesi ile uyumlu olmayan bir aritmetik başarı göstermesi, (2) standart matematik başarı testleri ile ölçülen matematik başarısı açısından yaşıtlarının veya bulunduğu sınıf düzeyinin en az iki yıl gerisinde kalması, (3) yaşına uygun standart aritmetik başarı testlerinde en alt düzey olarak nitelenebilmesi \%5-10 içinde bulunma ölçütlerine dayanmaktadır (Olkun, 2014). Burada zekâ testlerinin kültürden kültüre farklı sonuçlar gösterdiği ve halen tartı̧malı bir konu olduğunu göz önünde bulundurmakta yarar vardır. Bununla birlikte standart testlerin ise psikometrik olarak nitelikli, ölçüte veya norma dayalı olması gerekmektedir.

Matematik güçlüklerinin giderilmesi; doğrudan öğretimi, matematik temel becerilerini kazandırmaya ve geliştirmeye yönelik stratejileri, eğitim ortamlarının bireysel farklılıklara ve ihtiyaçlara göre düzenlenmesini ve zenginleştirilmesini, öğrenci becerilerinin ve öğrenme ortamlarının sürekli değerlendirilmesini ve değerlendirme sonuçlarının yorumlanarak sistematik bir müdahale programının kullanılmasını kapsamaktadır. Alanyazında matematik güçlügünün giderilmesine yönelik birçok uygulamanın önerildiği görülmektedir (Bender, 2012; Tuğrul-Kalaç, 2015; Olkun, 2014). Bireyselleştirilmiş eğitim uygulamaları (Re, Pedron, Tressoldi ve Lucangeli, 2014; Fuchs vd., 2008), strateji öğretimi (Fuchs vd., 2010; Swanson, Moran, Bocian ve Zheng, 2012; Swanson, Lussier ve Orosco, 2013, 2014, 2015; Uberti, Mastropieri ve Scruggs, 2004), akran öğretimi, grupla veya bireysel çalışma, müdahaleye tepki programları (Byrant, Byrant, Gersten, Scammacca ve Chavez, 2008) bu uygulamalardan sadece birkaçıdır. Tüm bu uygulamaların güçlüklerin doğru tanımlanması ön şartyyla uygulanabileceğini de söylemek gerekir. Ayrıca matematik güçlüklerinin giderilmesine yönelik uygulama ve müdahale programlarının odak noktasının güçlükten kaynaklanan bireysel farklılıklar ve öğrenme ortamının zenginleştirilmesi olduğunu söylemek mümkündür.

Okuma ve Matematik Güçlüklerinin Giderilmesinde Sınıf Öğretmeninin Rolü Perspektifinde: Sınıf öğretmeni adaylarının eğitimi

Sınıf öğretmenlerinin, öğrencilerine okuma becerileri ve matematiksel becerileri kazandırmada ve geliştirmede teşvik edici olmaları gereklidir. Okuma için öğretimin temellerini; çıkarımda bulunma, anlamı yapılandırma ve strateji- 
ler oluşturmaktadır (Akyol, 2005). Matematik öğretiminin temellerini ise; matematiksel kavramlar, ilkeler ve süreçler oluşturur (Haylock ve Cockburn, 2014). Bu iki temel beceri için ortak nokta ise iyi bir öğretimle birlikte öğrencilerin bireysel farklılıklarının göz önünde bulundurulması ve öğretim ortamının zenginleştirilmesidir. Sınıf öğretmenlerinin öğrenme-öğretme ortamını hazırlaması ve zenginleştirmesi, öğrenmeleri anlamlı kılması ve bunların yanı sıra öğrencilerin performans ilerlemelerini ve beceri gelişimlerini izlemesi gerekir. Türkiye'de gelişim raporları çoğunlukla öğrencilerin akademik başarısına ilişkin değerlendirmeyi içermektedir. Ancak öğrencilerin okuma ve matematik konusunda yaşadıkları güçlüklerin tespit edilmesi ve zamanında müdahale edilebilmesi için gelişim raporlarından daha kapsamlı ve ayrıntılı izleme raporlarına ihtiyaç duyulduğunu söylemek mümkündür. Karşılaştırma amaçlı olarak, diğer ülkelere bakıldığında ise öğrencilerin yaşadıkları güçlüklerin tespiti ve giderilmesi için, sınıf öğretmenlerinin okuma uzmanı veya destek öğrenme öğretmeninden yardım aldıkları görülmektedir. Bununla birlikte mevcut izleme ve tanılama sistemleri okullarda işlevsel olarak çalışmaktadır (Bender, 2012). Türkiye'de tanılama süreci sınıf öğretmeninin özel öğrenme güçlüğü riski taşıdığını düşündüğü öğrenci ve tanılama süreci hakkında öğrencinin ailesini bilgilendirmesiyle başlar. Aile öğrencinin tanılama sürecine dâhil olmasını isterse tıbbi kontrollerinin yapılması amacıyla öğrenci ilk olarak tıbbi tanılama alır. Tıbbi tanılama sonrasında öğrenci eğitsel tanı alması için Rehberlik Araştırma Merkezlerine (RAM) yönlendirilmesi gerekir (Kuruyer ve Çakıroğlu, 2017; Görgün, 2017; Özyürek, 2015). RAM'da yapılan değerlendirme ve tanılama süreci sonucunda tanı alan öğrenci kaynaştırma ve destek eğitimi alır.

Okuma ve matematik güçlüğü yaşayan bireyler özellikle okul dışında ailelerinden güçlükleri ile ilgili doğru bir yönlendirme ve yardım alamamaktadırlar. Bu öğrenciler okulda öğretmen tarafindan yapılan okuma ve matematik becerilerine yönelik etkinliklerle yetinmek durumunda kalmaktadırlar. Genellikle bu öğrencilerin yaşadıkları güçlükler tespit edilse bile güçlüklerini gidermeye yönelik yeterli destek eğitimin sağlanması sürecinde problem yaşandığı bilinmektedir (Güzel-Özmen, 2008). Sınıf öğretmenleri, okuma ve matematik güçlüklerinin tespit edilmesinde ve müdahale programlarının uygulanmasında kritik önem taşımaktadır (Melekoğlu, 2017; Williams, 2013). Ancak yapılan araştırmalar sınıf öğretmenlerinin okuma ve matematik güçlüklerine ilişkin bilgi eksiklerinin olduğu ve kavram yanılgılarına sahip olduklarını göstermektedir (Başar ve Göncü, 2018; Kuruyer ve Çakıroğlu, 2017). Bu bakış açısıyla sınıf öğretmeni yetiştiren programlar öğrencilerinin okuma ve matematik güçlüklerine yönelik farkındalık, bilgi ve söz konusu güçlüklerin giderilmesine yönelik deneyim sahibi olmasını amaçlamalıdır. Ancak Türkiye'de Sınıf Öğretmenliği Bilim Dalı Lisans programlarının ders içerikleri (YÖK, 1998) incelendiğinde okuma ve matematik güçlüklerine yönelik teorik ve uygulamalı derslerin olmadığı görülmektedir. Bu durum Türkiye'de sınıf öğretmeni adaylarının okuma ve matematik güçlüklerine ilişkin yeterli bilgi ve beceri kazanamadıklarının göstergesi olarak yorumlanabilir.

Dünyada mevcut akademik çalışmalar ve uygulamalar düşünüldüğünde Türkiye'de okuma güçlükleri ve matematik güçlüklerinin giderilmesine yönelik çalışma, araştırma ve uygulamaların yetersiz olduğunu söylemek mümkündür (Akyol ve Yıldız, 2013; Hacısalioğlu-Karadeniz, 2013; Grünke ve Morrison-Cavendish, 2016; Özkardeş-Güngörmüş, 2013). Türkiye'de okuma ve matematik güçlükleri ilkokula devam eden öğrencilerde yaygın olarak görüldüğü varsayılmakta ve mevcut okullarda bu alanlara ilişkin uzman olmadığı bilinmektedir (Akyol, Çakıroğlu ve Kuruyer, 2014; Akyol ve Yıldız, 2013; Altun, Ekiz ve Odabaşı, 2011; Bintaş, 2007; Sezer ve Akın, 2011). Türkiye'de özel öğrenme güçlüğü tanısı almış öğrenci sayısı oranının 2013-2014 öğretim yılında örgün eğitimde özel eğitim hizmeti alan tüm öğrenciler arasında \%3 olduğu belirtilmektedir (Melekoğlu, 2017). Mevcut durum göz önünde bulundurulduğunda, okuma ve matematik güçlüklerinin giderilmesinde sınıf öğretmeninin önemini ve sınıf öğretmenlerinin eğitiminin bu konu üzerine yapılandırma intiyacını ortaya koymaktadır.

'Öğretmen adaylarının bilgi, beceri ve deneyim bakımından kendilerini algılama ve kendilerini yargılama biçimi, meslek yaşamları boyunca etkili öğretim hizmeti vermelerinde ve karşılaştıkları pedagojik zorluklarla baş edebilmelerinde önemli rol oynamaktadır' (Özdemir, 2008: s. 277). Bununla birlikte öğretmenlerin geçmiş deneyimleriyle kazandıkları inanç ve beklentiler, öğretim planlama sürecinde ve öğrencilerine karşı yaklaşımlarında etkili olmakta ve kolaylıkla değiştirilememektedir (Woolfolk-Hoy \& Spero, 2005). Bilindiği üzere öğretmen eğitiminde öğretmen adaylarının sahip olduğu inanç ve tutumlar dış kaynaklardan daha etkilidir (Woodcock, 2013). Alan yazın incelendiğinde, Türkiye'de sınıf öğretmenlerinin özel öğrenme güçlüğüne yönelik sahip oldukları bilgi ve kavram yanılgılarını belirlemeye yönelik çalışmaların (Altun ve Uzuner, 2016; Başar ve Göncü, 2018; Doğan, 2013; Kuruyer ve Çakıroğlu, 2017) olduğu görülmüştür. Ancak sınıf öğretmeni adaylarıyla yapılan ve okuma ve matematik güçlük alanlarına odaklanan ve pedagojik farkındalıklarını ve öğretimsel bakış açılarını belirlemeye yönelik bir çalışmaya rastlanmamıştır. Bu bakış açısıyla araştırmanın amacı, sınıf öğretmeni adaylarının okuma ve matematik güçlüklerine ilişkin pedagojik farkındalıklarının ve öğretimsel bakış açılarının belirlenmesidir. Bu amaç doğrultusunda (1) Sınıf öğretmeni adaylarının okuma ve matematik güçlüklerine ilişkin pedagojik farkındalıklarını nelerdir? (2) Sınıf öğretmeni adaylarının okuma ve matematik güçlüklerine ilişkin öğretimsel bakış açıları nelerdir? sorularına cevap aranmıştır. 
Okuma ve matematik güçlükleri özellikle ilkokulun ilk sınıflarında ortaya çıkan ve belirtileri görülen olgulardır. Sınıf öğretmenleri de ilkokulun 1-4. sınıflarında eğitim veren öğretmenler olduğu için okuma ve matematik güçlükleri konusunda pedagojik farkındalıklara ve öğretimsel bilgiye ve beceriye ihtiyaçları olacağı varsayılmıştır. Araştırma yalnızca sınıf öğretmeni adayları ve bu öğretmen adaylarının okuma ve matematik güçlüklerine ilişkin pedagojik farkındalıklarını ve öğretimsel bakış açılarını belirlemek amacıyla sınırlandırılmıştır. Araştırmanın, sınıf öğretmeni adaylarının okuma ve matematik güçlüklerine ilişkin pedagojik farkındalıklarııın ve öğretimsel bakış açıları dikkate alınarak mevcut sınıf öğretmenliği lisans programlarında bazı düzenlemeler yapılması açısından oldukça önemli olduğu düşünülmektedir. Ayrıca, bu araştırmadan elde edilen bulguların okuma ve matematik güçlüklerinin değerlendirilmesinde sınıf öğretmenlerinin rollerinin ve öğretimsel görev çerçevesinin oluşturulmasında, okuma ve matematik güçlüklerine yönelik mesleki alan yeterliliklerinin belirlenmesinde alan yazına katkı sağlayacağı öngörülmektedir.

\section{Yöntem}

Bu araştırmada, sınıf öğretmeni adaylarının okuma ve matematik güçlüklerine ilişkin pedagojik farkındalıklarını ve öğretimsel bakış açılarını belirlemek amacıyla "durum çalışması yöntemi" kullanılmıştır. Katılımcıların pedagojik farkındalıkları ve öğretimsel bakış açılarını analiz birimi olarak kabul edildiğinden araştırma iç içe geçmiş çoklu durum deseniyle yürütülmüştür. Durum araştırması sonuçları, neden ve sonuçların belirleyicisi olan gerçek bağlamda gözlemleyerek ortaya koymaktadır (Cohen, Manion ve Morrison, 2007).

\section{Katilımcilar}

Araştırma; Sınıf Öğretmenliği Lisans Programına üçüncü ve dördüncü sınıfta öğrenimlerine devam etmekte olan 73 öğretmen adayı ile gerçekleştirilmiştir. Araştırmanın katılımcıları amaçlı örnekleme yöntemlerinden ölçüt örnekleme kullanılarak belirlenmiştir. Bu katılımcıların seçilmiş olmasının nedenini Sınıf Öğretmenliği Lisans programında üçüncü sınıf dersleri olan İlkokuma Yazma Öğretimi, Türkçe Öğretimi, Matematik Öğretimi I ve II derslerini almış olmaları şeklinde açıklamak mümkündür. Bununla birlikte 'okuma ve matematik güçlükleri'ne yönelik seçmeli ders alan öğrenciler çalışma grubunun dışında bırakılmıştır. Araştırmaya katılan öğretmen adayları araştırma ile ilgili bilgilendirilmiş ve gönüllü katılımları sonucunda çalışılmaya başlanmıştır.

\section{Veri Toplama Araçları}

Görüşme Formu. Araştırmada araştırmacılar tarafindan geliştirilen yarı yapılandırılmış görüşme formu kullanılmıştır. Görüşme formu oluşturulurken öncelikle araştırmanın amacı doğrultusunda ilgili alan yazın (Butterworth, Varma ve Laurillard, 2011; Gifford ve Rockliffe, 2008; Jaya ve Geetha, 2009; Singh ve Agarwal, 2011; Snowling, 2012; Torgessen, 2002; Williams, 2013) taranmıştır. Alan yazın taraması sonucunda okuma ve matematik güçlüklerine ilişkin 10 madde belirlenmiş ve görüşme formunun ilk şekli bu 10 maddeden oluşmuştur. Görüşme formu üç alan uzmanının incelemesi sonrasında oluşan görüşleri doğrultusunda yeniden düzenlenmiş ve madde sayısı 8'e düşürülmüştür. Sekiz maddelik görüşme formu, anlam ve anlaşılırlık açılarından değerlendirilmek üzere çalışma grubunda yer almayan ve katılımcı olarak araştırmaya dâhil olmak için gerekli ölçütleri sağlayan 8 öğretmen adayına uygulanmıştr. Ön uygulamadan sonra görüşme formuna son hali verilerek geçerli bir veri toplama aracı elde edilmiştir.

Yarı yapılandırılmış görüşme formunda yer alan sorular aşă̆ıda belirtilmiştir;

- Okuma güçlüğü nedir? Kısaca açıklar mısınız?

- Illkokulda okuma güçlüğü nasıl gözlenir?

- Okuma güçlükleri nasıl tespit edilir?

- Okuma güçlüklerini gidermek üzere nasıl bir yol izlenmelidir?

- Matematik güçlüğü nedir? Kısaca açıklar mısınız?

- Iilkokulda matematik güçlüğü nasıl gözlenir?

- Matematik güçlükleri nasıl tespit edilir?

- Matematik güçlükleri nasıl giderilir?

Ancak sınıf öğretmeni adaylarının lisans eğitimi süresince okuma veya matematik güçlüğü yaşayan bireylerle deneyim kazanma imkânının olmaması araştırma açısından bir sınırılık olarak düşünülmüştür. Bu sınırııı̆ı en aza indirmek ve araştırmaya esas bulguların elde edilebilmesi için öğretmen adaylarına görüşme formunun yanısıra okuma ve matematik güçlüğü yaşayan öğrencilere ilişkin durumlar sunan okul öyküleri ve videolar kullanılmıştır.

Okul Öyküleri. Öğretmen adaylarına (ilkokula devam eden öğrencilerin yaşadıkları okuma ve matematik güçlükleri 
açısından) değerlendirmeleri için yazılı olarak iki okul öyküsü sunulmuştur. Okul öyküleri oluşturulurken öncelikle ilgili alan yazın (Bender, 2012; Garner, 2008; Schunk, 2010) taranmıştr. Okul öyküleri öğrencilerin okuma performansı ve matematik performansı hakkında ipuçları verse de öğretmen adayından beklenen bütün olası tanılama kriterlerini göz önünde bulundurarak bir değerlendirme yapmasıdır.

Okul Öyküsü 1. Nehir illkokul 4. sınıf öğrencisidir. Nehir okulda dersleriyle ilgili sürekli sorun yaşamaktadır. Dördüncü sınıfin ilk döneminde Sosyal Bilgiler ve Fen ve Teknoloji derslerinde başarısız olmuştur. Matematik dersinde dört işlem becerileriyle ilgili sorun yaşamamasına rağmen sözel matematik problemlerini çözerken sorun yaşamaktadır. Nehir okumaya dayalı sınıf çalışmalarına katılmak konusunda isteksiz görünmektedir. Ev ödevlerini genelde unuttuğunu söylemekte veya tamamlamadan getirmektedir.

Okul Öyküsü 2. Batuhan 2. ve 3. sınıfta matematik dersinde başarısız olmuştur. 4. Sınıfta matematik derslerinde katılım konusunda isteksiz, yapılan etkinliklere ilgisiz olduğu gözlenmiştir. Matematik defteri incelendiğinde genellikle işlemlerin yarım bırakıldığı görülmüştür. Yapılan işlemlerde ise hatalar olduğunu söylemek mümkündür.

Okuma ve Matematik Güçlüğü Yaşayan Öğrencilere ilişkin Videolar. Okuma ve matematik güçlüğü yaşayan öğrencilere ilişkin videoların hazırlanması için Aksaray ilinde tesadüfi yolla belirlenen üç okulda çalışıımıştr. Öncelikle üçüncü ve dördüncü sınıf öğretmenlerinin sınıflarında okuma ve matematik güçlüğü riski taşıdığını düşündükleri öğrencilerle ön görüşmeler yapılmışttr. Altı okuma ve alt matematik güçlüğü yaşadığı düşünülen 12 öğrencinin ailesiyle görüşme saati ayarlanmıştır. Veliler yapılan görüşmede çalışma hakkında bilgilendirilmişlerdir. Görüşmeler sonucunda ailelerinin onamıyla çalışmada yer almak isteyen dört öğrenciye eğitsel değerlendirme amaçlı olarak yaşadıkları güçlükleri belirlemek üzere Erden (2006) tarafindan geliştirilen Özel Öğrenme Güçlüğü Bataryası kullanılmıştrr. Eğitsel değerlendirme sonrasında, 2 öğrenciyle okuma çalışmaları, 2 öğrenciyle ise matematik çalışmaları video kaydına alınmıştr. Bu video kayıtları iki alan uzmanı tarafindan incelenerek ortak kanı sonucunda Video 1 ve Video 2'nin kullanımına karar verilmiştir. Video-1 30, video-2 25 dakika uzunluğundadır. Videoların veri toplama aracı olarak kullanılması için gerekli izinler alınmıştı. Öğretmen adaylarından beklenen Video 1 ve Video 2'de yer alan durumu okuma ve matematik güçlüklerine göre değerlendirmeleri ve nasıl bir yol izleyeceklerini açıklamalarıdır.

Video-1. Videoda ses farkındalığı, kelime tanıma ve okuduğunu anlama becerilerinde güçlük yaşayan bir dördüncü sınıf öğrencisinin görüntülerine yer verilmiştir. Video kapsamında öğrenci ses çalışmaları, kelime seslendirme, metin seslendirme, okuduğunu anlama sorularına yanıt verme ve okuma alt becerilerine yönelik görevlerle meşgul olmaktadır.

Video-2. Videoda problem çözme, ilişkilendirme, akıl yürütme becerilerinde ve dört işlem, veri, geometri öğrenme alanlarından güçlük yaşayan bir üçüncü sınıf öğrencisinin görüntülerine yer verilmiştir. Video kapsamında öğrenci, söz konusu öğrenme alanlarına ve becerilere yönelik görevle meşgul olmaktadır.

Okul öyküleri ve videolar öğretmen adaylarına örnek durumlar üzerinde çalışma olanağı sağlaması bakımından önem taşımaktadır.

Gönüllü Katılım Formu. Gönüllü kathlım formunda araştırmaya ilişkin kısa açıklamalara yer verilmiştir. Bununla birlikte, bu araştırma neden yapılıyor, neden bu araştırma sınıf öğretmeni adaylarıyla yapılıyor, araştırmada katılımcıdan beklenenler, elde edilen verilerin nasıl saklanacağı alt başlıklarından oluşmaktadır.

\section{Verilerin Toplanması}

Araştırmada veriler üç aşamada toplanmıştır. Birinci aşamada okuma ve matematik güçlüklerine iliş̧in sekiz sorudan oluşan yarı yapılandııımış görüşme formu uygulanmıştır. İkinci aşamada, okuma ve matematik güçlüğü yaşayan öğrencilere ait okul öyküleri verilerek öğretmen adaylarının, okul öykülerini öğrencilerin yaşadıkları güçlükler açısından değerlendirmeleri istenmiştir. Üçüncü aşamada ise okuma güçlüğü ve matematik güçlüğü yaşayan öğrencilere ait görüntü kayıtları öğretmen adaylarına izlettirilmiş öğrencilerin yaşadıkları güçlükleri ve güçlükleri gidermede kullanacakları yöntemleri tespit etmeleri istenmiştir. Videolarla birlikte öğrencilerin etkinlik kapsamında üzerinde çalıştğı metin ve çalışma kâğıtları öğretmen adaylarına detaylı değerlendirme yapmalarına olanak sağlamak üzere verilmiştir.

\section{Verilerin Analizi}

Araştırma sonucunda elde edilen veriler betimsel analiz yöntemiyle değerlendirilmiştir. Bu yönteme göre elde edilen veriler, daha önceden belirlenen temalara göre özetlenir ve yorumlanır. Betimsel analizde temel amaç, elde edilen bulguları düzenlenmiş ve yorumlanmış bir biçimde okuyucuya sunmaktır. (Yıldırım ve Şimşek, 2008:224). 
Bu araştırmada elde edilen verilerin analizinde şu aşamalar izlenmiştir:

- Temaların belirlenmesi

- Verilerinin transkript edilmesi

- Temalara göre verilerinin düzenlenmesi

- Verilerin çözümlenmesi ve yorumlanması

Sınıf öğretmeni adaylarının okuma ve matematik güçlüklerine ilişkin pedagojik farkındalıklarının ve öğretimsel bakış açılarının belirlenmesinde kullanılan görüşme formundan, okul öyküleri ve videolar aracılı̆̆ıyla sunulan durumlardan elde edilen veriler derinlemesine bilgi edinmeye olanak sağlamıştr. Temalar ve veri analiz sürecinde tanılanan bulgular, araştırmacılar ve bağımsız bir uzman tarafindan incelenmiştir. Pedagojik farkındalıkları ve öğretimsel bakış açılarını analiz birimini, okuma ve matematik güçlükleri kavramı, okuma ve matematik güçlüklü öğrencilerin özellikleri, okuma ve matematik güçlüğünün tespiti ve okuma ve matematik güçlüğünün desteklenmesi ise alt analiz birimleri (kategoriler) olarak ele alınmıştır. Analiz birimleri temaları, alt analiz birimleri ise kategorileri oluşturmuştur. Temalar, kategoriler ve kategorileri oluşturan sorular Şekil 1'de sunulmuştur.

\section{Tema: Okuma güçlüğüne ilișkin pedagojik farkındalık}

\section{Kategoriler}

-Okuma güçlüğü nedir? Kısaca açıklar mısınız? ( $\left.a_{1}\right)$

-İlkokulda okuma güçliuğü nasıl gözlenir? $\left(b_{1}\right)$

- Okuma güçlükleri nasıl tespit edilir? $\left(\mathrm{c}_{1}\right)$

- Okuma güçlüklerini gidermek üzere nasil bir yol izlenmelidir? $\left(d_{1}\right)$

\section{Tema: Matematik güçlüğüne ilișkin pedagojik farkındalık}

\section{Kategoriler}

- Matematik güçlüğü nedir? Kısaca açıklar mısınız? $\left(a_{2}\right)$

-İlkokulda matematik güçlüğü nasıl gözlenir? $\left(\mathrm{b}_{2}\right)$

- Matematik güçlülkleri nasil tespit edilir? $\left(\mathrm{c}_{2}\right)$

-Matematik güçlükleri nasil giderilir? $\left(\mathrm{d}_{2}\right)$

Tema: Okuma güçlüğüne ilişkin öğretimsel bakıș açıları

Kategoriler

-Okul öyküsü $1^{\prime} i$ okuma güçlüklerine göre değerlendiriniz. $\left(a_{1}, b_{1}, c_{1}\right)$

-Video 1 'de izlediğiniz öğrenciye ilişkin izleyeceğiniz yolu açıklayınız. $\left(d_{1}\right)$

\section{Tema: matematik güçlüğüne ilişkin öğretimsel bakış açıları}

\section{Kategoriler}

- Okul öyküsü 2'yi matematik güçlüklerine göre değerlendiriniz. $\left(a_{2}, b_{2}, c_{2}\right)$

-Video 2 'de izlediğiniz öğrenciye ilişkin izleyeceğiniz yolu açıklayınız. $\left(\mathrm{d}_{2}\right)$

$\left(a_{1}:\right.$ okuma güçlüğü kavramı, $a_{2}$ : matematik güçlüğü kavramı; $b_{1}:$ okuma güçlüklü öğrencilerin özellikleri, $b_{2}:$ matematik güçlüklü öğrencilerin özellikleri; $c_{1}$ : okuma güçlüğünün tespiti, $c_{2}$ : matematik güçlüğünün tespiti; $d_{1}$ : okuma güçlüklü öğrencilerin desteklenmesi, $\mathrm{d}_{2}$ : matematik güçlüklü öğrencilerin desteklenmesi)

\section{Şekil 1. Temalar ve kategoriler}

Tema 1'de sorulan 'Okuma güçlüğü nedir?' sorusu öğretmen adaylarının okuma güçlüğüne ilişkin pedagojik farkındalıklarını (bilgi ve yanılgılarını) belirlemek amacıyla sorulmuştur. Buradaki amaç, öğretmen adaylarının okuma güçlüğü kavramını nasıl tanımladıklarına dönük bilgi ve yanılgılarını ortaya çıkarmaktır. Analiz işleminin nasıl yapıldığını açıklamak için Öğretmen adayı 4, Öğretmen adayı 17 ve Öğretmen adayı 45'in Tema 1'e yönelik verdiği yanıtlar ve yanıtların analiz süreci örnek olarak verilebilir. Öğretmen adayı 4 Okuma güçlüğü nedir? sorusuna 'Kelimedeki bazı harfleri yanlış okumasıdır.', Öğretmen adayı 17 'Harfleri birleştirip hece, hecelerden kelime oluşturma da sıkınt çekmektir.', Öğretmen 
adayı 45 'Kelimeleri tanıyamayan kişilerin okurken zorlanması' ve 'Harfleri tam seçemeyerek karıştırarak okuyamamasıdır.' şeklinde yanıtlar vermişlerdir. Öğretmen adaylarının verdiği yanıtlar incelendiğinde okuma güçlüğünü kelime seslendirmede ki hatalar olarak tanımladıkları görülmektedir. Öğretmen adaylarının yanıtları ilgili alan yazın (Dirks, Spyer, van Lieshout, ve de Sonneville, 2008; DSM IV, 2000; Geary, 1993; Landerl, Fussenegger, Moll, ve Willburger, 2009) dikkate alınarak çözümlenmiş ve yorumlanmıştr. Örneğin; okuma güçlüğü bireyin zekâ veya zihinsel bir problemi olmamasına rağmen ses farkındalığı, kelime tanıma-kelime ayırt etme, okuduğunu anlama becerilerinde akranlarına göre güçlükler yaşaması ölçütüne göre bir öğrencinin kelimedeki bazı harfleri yanlış okuması okuma güçlüğü olarak değerlendirilmesi uygun değildir. Söz konusu öğretmen adaylarının yanıtları okuma güçlüğüne ilişkin pedagojik farkındalıkları açısından bilgi eksikliği olarak yorumlanmıştır. Bu kapsamda bütün öğretmen adaylarının yanıtları her bir tema için Word dosyasına aktarılmıştır. Yanıtlar araştırmacılar tarafindan üç hafta arayla incelenerek tekrar okunmuştur. Çaıışma grubunda yer alan öğretmen adaylarının yanıtlarının nasıl anlamlandırılabileceği ve yorumlanabileceği tartşıllarak araştırmanın bulguları oluşturulmuştur.

Araştırmanın iç geçerliği; elde edilen verilerin ayrıntılı olarak rapor edilmesi, doğrudan alıntılara yer verilmesi ve bu alıntılardan yola çıkarak bulguların objektif olarak açıklanmasıyla sağlanmaya çalışımıştı. Araştırmanın dış geçerliği ise, araştırma sürecinin ve bu süreçte yapılanların ayrıntılı bir şekilde açıklanarak sağlanmaya çalışıımıştır. Araştırmada güvenirlik amacıyla, tüm veriler araştırmacılar dışında bir alan uzmanı tarafindan da okunmuştur. Miles ve Huberman'ın (1994) belirttiği güvenirlik formülü ile $p=.94$ bulunmuştur.

\section{Uygulama Süreci}

Tüm uygulamalar öğretmen adaylarıyla önceden belirlenen tarih ve saatte sessiz bir ortamda gerçekleştirilmiştir. Uygulama öncesinde araştırmacılar tarafindan öğretmen adaylarına araştırma hakkında bilgi verilmiş ve gönüllü katılım formları dağıtılmıştr. Araştırmaya katılan öğretmen adaylarının hepsi gönüllü katılımlarını beyan etmişlerdir. Tüm uygulamalar yaklaşık 120 dakika sürmüştür.

\section{Bulgular ve Yorumlar}

Öğretmen adaylarının okuma güçlüğü ve matematik güçlüğüne ilişkin sorulara verdikleri yanıtlar, pedagojik farkındalık ve öğretimsel bakış açıları temaları altında sunulmuştur.

\section{1.a.) Öğretmen adaylarının okuma güçlüklerine yönelik bilgi ve farkındalıklarına ilişkin bulgular}

\section{Tema 1. Okuma güçlüğüne ilişkin pedagojik farkındalık}

Okuma güçlüğü nedir? Sorusuna katılımcıların verdikleri yanıtlar incelendiğinde katılımcıların çoğu okuma güçlüğünü; bireyin harfleri doğru seslendirememesi, heceleyerek okuma, harfler arasında doğru bağlantları kuramama, metni uygun hızda okuyamama şeklinde ifade etmişlerdir. Katılımcıların sadece üçü okuma güçlüğünü, okuduğunu anlamada yaşanan güçlükler ve okuma güçlüğüne sahip olan bireylerin akranlarına göre okuma performanslarının beklenilen düzeyde olmaması şeklinde ifade etmişlerdir. Bu durumu açıklayan örnekler aşağıda sunulmuştur.

Ö.A. 63. Öğrencinin ses farkındalı̆̆ını bilmemesi, okuduğunu anlayamaması, kelimeleri tanıyıp, ayırt edememesidir.

Ö.A. 50. Okuma güçlüğü, herhangi bir çocuğun aldığı derslere rağmen diğer akranlarına oranla okumasının daha zayıf olmasıdır.

Katılımcılardan 11'i okuma güçlüğünü engellilik durumu, kekeleme, hastalık, sadece ilkokul düzeyinde görülen bir durum, telaffuz problemi olarak ifade etmişlerdir. Katılımcıların sadece biri okuma güçlüğünü tanımlarken metni seslendirmede yaşanan güçlüklerle birlikte okuma güçlüğüne eşlik eden bilişsel ve duyuşsal sorunlara değinmiştir. Bu durumu açıklayan örnek aşağıda sunulmuştur.

Ö.A.23. Okuma güçlügü ise bireyin okumaya ilişkin geliştirmesi gereken parçaları birleştirememesidir. Dikkatsiz olması, ilgisiz olması gibi nedenlerden dolayı güçlükler yaşamasıdır. Bu güçlükler bilişsel, duyuşsal, psikolojik anlamadaki bozukluklardan da kaynaklanabilir.

Okuma güçlüğü olan bireylerin okuma performanslarının, yaş, zekâ düzeyi ve aldıkları eğitim göz önünde bulundurulduğunda akranlarına göre beklenilenin önemli derecede altında olduğu görülmektedir (İşeri ve Akın-Sarı, 2011). Bu kapsamda düşünüldüğünde öğretmen adaylarının çoğunun okuma güçlüğü hakkında bir farkındalığa sahip olsalar bile okuma güçlüğünün kapsamı hakkında yanılgılara sahip olduklarını söylemek mümkündür. 
İlkokulda okuma güçlüğü nasıl gözlenir? Sorusuna verilen yanıtlar incelendiğinde; katılımcıların çoğu öğrencinin metni seslendirirken yaptğ̆ hataların okuma performansını ortaya koyacağı ve okuma güçlüğü yaşayıp yaşamadığına ilişkin genel bir kanının oluşacağını belirtmişlerdir. Eğer öğrenci kelimeyi seslendirirken takılıyorsa, kelimeyi yanlış seslendiriyorsa, heceleyerek okuyorsa, parmak takibi yapıyorsa okuma güçlüğü gözlenebileceğini ifade etmişlerdir. Okuduğunu anlama becerisine yönelik performansın okuma güçlüğü gözlenirken temel ölçütlerden biri olduğunu belirten olmamıştır. Bu durumu açıklayan örnek aşağıda sunulmuştur.

Ö.A. 53. Çocuk uzun zaman geçmesine rağmen harfleri tanıma da sıkıntı çeker, harfleri tanıma da sıkıntı çeker, harfleri karıştırır, yanlış seslendirir. Okuma konusu olunca kasılır, sıkılır, okumak istemez. Ses ve tonlamasını ayarlayamaz, parmağı ile kelime heceleri takip eder. Kelimeleri eksik ya da yanlış okur. (Fazla hece de ekleyebilir.)

Okuma güçlüğü olan öğrencilerin yanlış okuma, harf-hece atlama, harf-hece ekleme, farklı sözcük okuma, okunan kelimenin bir kısmını tekrarlama gibi hataları yapma oranının daha fazla olduğunu ve okuma güçlüğü olan öğrencilerin okuma akıcılığının doğruluk, otomatiklik ve prozodi boyutlarının tümünde sorun yaşadıklarını söylemek mümkündür. Bununla birlikte bu öğrenciler dikkat, bellek, öğrenme, görsel-mekânsal algılama sorunları da yaşamaktadır. (Baydık, 2014; Kuruyer, 2014). Bu kapsamda sınıfta söz konusu bu davranışları gösteren öğrencilerin okuma güçlüğü riski taşıdığı düşünülebilir. Öğretmen adaylarının yanıtları bu bakış açısıyla değerlendirildiğinde; öğretmen adaylarının okuma güçlüğüne ilişkin bilgi eksikliklerinin ve yanılgılarının olduğu söylenebilir. Bununla birlikte öğretmen adayları okuma güçlüğü riski taşıyan öğrencilerinin gösterdikleri okuma performanslarını değerlendirirken ölçütleri belirlemede güçlükler yaşayacaklarını söylemek mümkündür.

Okuma güçlükleri nasıl tespit edilir? Sorusuna verilen yanıtlar incelendiğinde; katılımcıların tamamına yakını okuma güçlüğünün sesli okuma çalışmaları aracılığıyla tespit edileceğini ifade etmişlerdir. Okurken ne tür hatalar yaptı̆̆ı, metni ne kadar sürede okuduğu ise üzerinde durulması gereken önemli kriterler olarak belirtilmiştir. Sadece iki öğretmen adayı okuma güçlüğünün tespitinde envanterlerin kullanabileceğini ifade etmiş ancak bu envanterlerin ne olduğunu açıklamamışlardır. İki öğretmen adayı ise okuma güçlüğünün uzmanlar tarafından tespit edilmesi gerektiğini belirtmiş ancak söz konusu tespitin ayrıntılarına değinmemişlerdir. Bir öğretmen adayı ise okuma güçlüğüne eşlik eden zihinsel problemlerin olup olmadığının da uzmanlar tarafindan incelenmesi gerektiğini belirtmiştir. Bu durumu açıklayan örnekler aşağıda sunulmuştur.

Ö. A. 20. Öğrenci sesli okuma yaparken harfleri tanıyıp tanımaması, kelimeleri yanlış okuyup okumamasına dikkat edilir.

Ö.A. 58. Okuma güçlüğü olan öğrenciler mutlaka uzman kişilerce edilmelidir. Bu iş içinde Rehberlik Araştrrma Merkezi incelemesi esastır. Öğretmen bu süreç dâhilinde ortaya çıkarmaya çalışmalıdır.

Okuma güçlüğü tespit edilmesinde izlenecek yolu ses farkındalığına, kelime tanıma-ayırt etme, okuduğunu anlama beceri ve performansına yönelik yapılan ayrıntlı tanılama, bireyin zekâ geriliği yaşamadığına ilişkin uzman görüşünün alınması, dikkat, bellek, algı problemlerinin dışlanması şeklinde tanımlamak mümkündür (Westwood, 2008). Bu yol göz önünde bulundurulduğunda öğretmen adaylarının okuma güçlüklerinin tespit edilmesinde izlenecek adımlar hakkında bilgi sahibi olmadıklarını söylemek mümkündür. Buradaki temel problemi öğretmen adaylarının okuma güçlüğünün belirtilerini ve kapsamını belirleyememek ve okuma performansına ilişkin detaylı ölçümlemenin nasıl yapılacağının farkında olmamaları şeklinde açıklamak mümkündür.

Okuma güçlüklerini gidermek üzere nasıl bir yol izlenmelidir? Sorusuna verilen yanıtlar incelendiğinde; güçlük yaşayan öğrencinin yaşadığı güçlüğün tespit edilmesi gerektiği, yaşadığı güçlüğe göre ve bireysel farklılıklarını dikkate alarak hazırlanmış destek programlarının önemine değinildiğini söylemek mümkündür. Öğrencinin yaşadığı güçlüklerle ilgili farkındalık kazanması gerektiğini ve bununla birlikte öğrenciye destek sağlamak amacıyla öğretmen ve veli işbirliğinin gerekliliğini belirtmişlerdir. Ancak programın detaylarının nasıl olması gerektiğinden, yardımcı stratejilerden ya da okuma güçlüğüne yönelik örnek uygulamalardan bahsetmedikleri görülmüştür. Bunun sebebini öğretmen adaylarının okuma güçlüklerini gidermeye yönelik uygulamalar hakkında bilgi sahibi olmadığı şeklinde açıklamak mümkündür. Bu durumu açıklayan örnekler aşağıda sunulmuştur.

\section{Ö.A. 1. Okuma güçlüklerini çözmek için bireysel farklılıklar önemsenmelidir}

Ö.A.12. Okuma güçlükleri ekstra bir çaba, gayret harcayarak giderilebilir. Bu durumu ortadan kaldırmak için öğrenci-veli ve öğretmen üçlüsü ortak hareket etmelidir. Öğretmen öğrencisiyle birebir görüşmelidir. Ona birebir ekstradan yardımcı olmalıdır. 
Okuma güçlüğünün giderilmesine yönelik birçok uygulama ve modelin önerildiği görülmektedir (Akyol, 2005; Bender, 2012). Kelime tanıma ve okuma becerisini geliştirmeye yönelik kullanılan zenginleştirilmiş okuma programı, akranla okuma, okuyucu tiyatroları, eşli okuma bu uygulamalardan sadece birkaçıdır (Dündar ve Akyol, 2014; Kuruyer, 2014). Modelleri ve müdahale programlarının uygulamasında temel kural güçlüğün giderilmesine yönelik olmasıdır. Öğrencinin fonolojik farkındalık, kelime hatırlama, kelime tanıma, anlama, dikkat, bellek, motivasyon sorunlarından hangisini ve hangilerini yaşadığı tespit edilmeli ve sorunu çözmek için müdahale programı uygulanmalıdır. Öğretmen adaylarının sorunlar ve müdahale programları hakkında bilgi eksikliklerine sahip olduklarını söylemek mümkündür. Bunun nedenleri, sınıf öğretmenliği adaylarının lisans programı süresince bu konuda yeterli ve kapsamlı bir içerikle karşılaşmamaları olabilir. Yine okuma güçlüğü ve bu güçlüğün eğitimi yeni yeni önem kazanmaya başlaması olduğu söylenebilir.

\section{1.b.) Öğretmen adaylarının matematik güçlüklerine yönelik bilgi ve farkındalıklarına ilişkin bulgular}

\section{Tema 2. Matematik güçlüğüne ilişkin pedagojik farkındalık}

Matematik güçlügü nedir? Sorusuna verilen yanıtlar incelendiğinde öğretmen adaylarının birçoğu matematik dersinin soyut olması ve matematik dersine karşı geliştirilen olumsuz tutum sebebiyle öğrencilerin yaşadıkları güçlükleri matematik güçlüğü olarak ifade etmişlerdir. Dört işlem becerilerinde yapılan hataların matematik güçlüğü olarak değerlendirildiği diğer bir bulgudur. Bu durumu açıklayan örnekler aşağıda sunulmuştur.

\section{Ö.A.6. Matematikte sayıların kavramların genel olarak soyut olması, öğrencinin matematiği anlamada ve öğrenmede zorluk çekmesidir.}

Ö.A.38. Öğrencilerin matematiği yapamayacaklarını düşünüp olumsuz tutum geliştirmelerinin sonucunda matematiği kavramada güçlük çekmesidir.

\section{Ö.A.68. Matematik güçlügü bir öğrencinin yaşına ve zekâ seviyesine uygun olarak matematikte gerekli başarıyı gösterememesidir.}

Ancak matematik güçlügü̈, bireyin takvim yaşı, ölçülen zekâ düzeyi ve yaşına uygun olarak aldığı eğitim göz önünde bulundurulduğunda beklenenin önemli ölçüde altında bulunan matematiksel becerilerinin olmasıdır (DSM-IV, 2000) şeklinde tanımlamak mümkündür. Bu tanım kapsamında matematik güçlükleri sadece dört işlem becerilerinde yaşanan güçlükler değil, problem çözme, matematiksel modelleme, akıl yürütme, ilişkilendirme, geometri, vb. becerilerde yaşanan güçlükleri de içermektedir. Sadece üç öğretmen adayı matematik güçlüğüne sahip olan bireylerin akranlarına göre matematik performanslarının beklenilen düzeyde olmaması şeklinde ifade etmiştir. Bu durumu açıklayan örnekler aşağıda sunulmuştur:

Ö.A.58. Matematik güçlüğü, aritmetik kavram ve becerilerin normal gelişim gösteren öğrencilerden daha alt seviyelerde seyir göstermesidir.

Ö.A.68. Matematik güçlüğü bir öğrencinin yaşına ve zekâ seviyesine uygun olarak matematikte gerekli başarıyı gösterememesidir.

İlkokulda matematik güçlüğü nasıl gözlenir? Sorusuna verilen yanıtlar incelendiğinde, öğretmen adayları matematik dersinde öğrencilerin yaptığı işlem hatalarının, problem çözerken güçlükler yaşamasının matematik güçlüğü yaşadığına ilişkin bir kanıya ulaşmak için yeterli olduğunu belirtmişlerdir. Nasıl gözleneceğine ilişkin detaylı bilgiler vermeseler de matematik güçlüğü yaşayan öğrencilerin matematik dersinde kaygılı olması, matematik derslerinde katılım göstermemesi ve matematik dersinde işlenen konuları anlamaması matematik güçlüğünün göstergelerinden olduğunu ifade etmişlerdir. Bu durumu açıklayan örnekler aşağıda sunulmuştur.

\section{Ö.A.11. Öğrencinin matematikten korkması en büyük göstergesidir.}

\section{Ö.A.72. Sınıf içinde yapılan dört işlem etkinliklerinde veya problemlerde gözlemlenebilir.}

Matematik güçlüğü yaşayan öğrenciler sayıları doğru okuyamama, basit toplama ve çıkarma işlemlerini gerçekleştirememe, aritmetik terimler ve sembolleri kavrayamama, matematik kurallarını ezberleyememe ve uzamsal yapıları anlayamama gibi sorunlar yaşarlar (Özkut, 2011). Bununla birlikte matematik güçlüğü olan öğrenciler basamak değeri, zaman ve nicelik gibi matematiksel kavramları algılamada, matematiksel bilgileri akılda tutmada, sayıları ve problemleri organize etmede güçlük yaşarlar (National Joint Committee on Learning Disabilities, 2000). Bu kapsam doğrultusunda öğretmen adaylarının yanıtları değerlendirildiğinde matematik güçlüğünün ve matematik güçlüğü yaşayan bir bireyin sahip olduğu güçlüklerin kapsamını doğru bir şekilde ifade edemediklerini söylemek mümkündür.

Matematik güçlükleri nasıl tespit edilir? Sorusuna verilen yanıtlar incelendiğinde, kathlımcıların tamamına yakını dört işlem performanslarına bakılarak tespit edilebileceğini belirtmişlerdir. Sadece üç öğretmen adayı birebir çalışma yapılması gerektiğini ifade etseler de birebir çalışmanın içeriğine ilişkin ayrıntılara değinmemişlerdir. Sadece bir öğ- 
retmen adayı matematik güçlüğünün test aracılığıyla tespit edileceğini belirtmiştir ancak testin içeriğine ilişkin bilgi vermemiştir. Öğretmen adaylarının matematik güçlüğünü tespit etmek için nasıl bir yol izlemeleri gerektiğini ve ne tür tanılama yöntemlerinin kullanacağı hakkında bilgi sahibi olmadıklarını söylemek mümkündür. Bu durumu açıklayan örnekler aşağıda sunulmuştur.

Ö.A.5. Öğrenciye matematiksel işlemler yaptırarak tespit edilebilir.

Ö.A.26. Öğrencilere matematiksel işlemlerin bulunduğu problemler verilir ve sonuçlar üzerinden değerlendirme yapılır. Öğrencilerle tek tek iletişim kurup, işlem yapmalarını gözlemlemek daha etkili bir çözüm olacaktır.

Matematik güçlüklerinin tespit edilmesinde izlenecek yolu, matematiksel işlemleri yapmada uzmanlaşmanın akranlarına göre geciktiğinin gözlenmesi, temel matematik becerilerinin ve performansının ayrıntılı olarak değerlendirilmesi, bireyin zekâ geriliği yaşamadığına ilişkin uzman görüşünün alınması, dikkat, bellek, algı problemlerinin dışlanması şeklinde tanımlamak mümkündür (Bender, 2012). Buradaki temel problemi, öğretmen adaylarının matematik güçlüklerini tanılamada ve bu güçlüklere ilişkin ölçümlemenin nasıl yapılacağına ilişkin bilgi eksikleriyle açıklamak mümkündür.

Matematik güçlükleri nasıl giderilir? Sorusuna verilen yanıtlar incelendiğinde güçlük yaşayan öğrencinin yaşadığı güçlüğün tespit edilmesi gerektiği, bireysel farklılıkları dikkate alarak hazırlanmış destek programlarının, günlük hayatla ilişkilendirmeler yapılan zengin öğrenme ortamlarının önemine değinildiğini söylemek mümkündür. Öğrencinin yaşadığı güçlüklerle ilgili farkındalık kazanması gerektiğini, öğrencinin sahip olduğu olumsuz tutumların değiştirilmesi ve bununla birlikte öğrenciye destek sağlamak amacıyla öğretmen ve veli işbirliğinin gerekliliğini belirtmişlerdir. Ancak söz konusu öğrenme ortamlarının nasıl zenginleştirileceğinden, uygulama içeriklerinden ya da matematik güçlüğüne yönelik örnek etkinliklerden bahsetmedikleri görülmüştür. Bunun sebebini öğretmen adaylarının matematik güçlüklerini gidermeye yönelik uygulamalar hakkında bilgi sahibi olmadığı şeklinde açıklamak mümkündür. Bu durumu açıklayan örnekler aşağıda sunulmuştur.

Ö.A.14. ... matematiği günlük hayatla ilişkilendirerek öğrencilere sevdirerek ve matematiğin korkulacak bir yüzünün olmadığını yaşayarak öğrenmelerini sağlama ile matematik güçlükleri giderilebilir.

Ö.A.55. Öncelikle öğrencinin bu derse karşı olumsuz önyargısı yok edilmelidir. Öğrencilerde matematik dersine karşı olumlu tutum geliştirilmelidir. Öğrencilerin sorun yaşadığı kısımlarda ek ders uygulamaları yapılmalıdır.

Ö.A.61. Öğrencilere zekâ ve yaş düzeylerine uygun etkinlikler yapılarak öğrencilerin bilgileri kendilerinin yapılandırılması sağlanır.

Matematik güçlüklerinin giderilmesine yönelik birçok uygulama ve öğretim yaklaşımının olduğunu söylemek mümkündür (Olkun, 2014). Matematiğe karşı olumlu tutum kazandırma ve matematik kaygı düzeyini azaltmak bununla birlikte öğrencinin güçlüklerine yönelik farkındalık kazanması için kullanılan günlük yazma, tam öğrenme modeli, öğretim yöntemleri, görseller ve sosyal etkileşim bakımından zenginleştirilmiş öğrenme ortamları bu uygulama ve yaklaşımlardan sadece birkaçıdır. Uygulama ve yaklaşımların kullanılmasında bireysel farklılıklar ve güçlüğün iyi analiz edilmiş olmasının kritik önem taşıdığını söylemek mümkündür.

\section{2.a.) Öğretmen adaylarının okuma güçlüklerine yönelik öğretimsel bakış açılarına ilişkin bulgular}

\section{Tema 3. Okuma gü çlüğüne ilişkin öğretimsel bakış açıları}

Okul öyküsü 1'i okuma güçlüklerine göre değerlendirdiklerinde, öğretmen adaylarının çoğunun okul öyküsünde öğrencinin yaşadığı durumu okuma güçlüğü olarak adlandırdığı görülmüştür. Okuma konusunda yaşadığı güçlüklerin fen ve sosyal dersleri etkilediğini, sözel problemlerde göstermiş olduğu düşük performansın sebebinin de okumada yaşadığı güçlükler olduğunu ifade etmişlerdir. Sadece bir öğretmen adayı okul öyküsünde yer alan bilgilerin okuma güçlüğüne işaret edebileceğini ancak genel bir değerlendirme yapabilmek için ayrıntılı bilgiye ihtiyaç olduğunu belirtmiştir. Bu durumu açıklayan örnekler aşağıda sunulmuştur.

Ö.A.25. Nehir'in sosyal ve fen derslerinde başarısız olmasının temelinde okuma güçlüğü çekmesi yatabilir. Çünkü okuma güçlüğü çeken birey okuduğunu anlamakta zorluk çeker....

Ö.A.34. Nehir okuma güçlüğü çektiği için okumaya karşı olumsuz bir tutum sergilemekte ve okuma üzerine olan derslere karşı ilgisiz kalmaktadır.

Video 1'de izlediğiniz öğrenciye ilişskin izleyeceğiniz yolu açıklayınız maddesine verilen yanıtlar incelendiğinde öğretmen adaylarının öğrencinin öncelikle yaşadığı güçlüklere odaklanıldığı görülmüştür. Öğretmen adaylarının çoğu öğrencinin yaşadığı güçlükleri, kelimeleri doğru seslendirememe, yavaş okuma, metinde olmayan kelimeleri söyleme

| Kastamonu Eğitim Dergisi, 27(4), 2019| 
eğilimi, heceleyerek okuma, okurken ekleme, eksik hece söyleme, odaklanma şeklinde sıralamışlardır. Güçlükleri gidermeye yönelik önerileri ise ailesini bilgilendirme, öğrencinin yaşadığı güçlükler konusunda farkındalık oluşturma, yoğun okuma çalışmaları, okuma öğretimini yineleme şeklinde belirtmişlerdir. Öğretmen adaylarının çoğunun okuduğunu anlamada yaşanan güçlükleri göz ardı ettiğini söylemek mümkündür. Bununla birlikte güçlükleri gidermeye yönelik önerilerde bulunsalar da önerilerin geniş kapsamlı, güçlük gidermeye yönelik teknik, strateji ve programları kapsamadığı söylenebilir. Bu durumu açıklayan örnek aşağıda sunulmuştur.

Ö.A.4. ... Uzun hikâyeler yerine kısa paragraflık metinler okuturuz. Bu metinlerdeki kelimeleri ve harfleri tam olarak okumasını isteriz. Hata yapıyorsa tekrar okuması istenmelidir. Okuduğu kelimelerin anlamları sorulmalıdır. Cümleyi okuduktan sonra ne anladığı sorulmalıdır. Velilerden de ona yardımcı olması ve sık sık kısa hikâyeler okutmaları istenmelidir. Arkadaş çevresi ile oyunlar yardımıyla metin okuma yarışmaları yaptirılmalıdır.

\section{2.b.) Öğretmen adaylarının okuma güçlüklerine yönelik öğretimsel bakış açılarına ilişkin bulgular}

Tema 4. Matematik güçlüğüne ilişkin öğretimsel bakış açıları

Okul öyküsü 2'yi matematik güçlüklerine göre değerlendirdiklerinde öğretmen adaylarının çoğunun okul öyküsünde öğrencinin yaşadığı durumu matematik güçlüğü olarak adlandırdığı görülmüştür. Öğrencinin yaşadığı sorunları matematik güçlüğüne eşlik eden ilgisizlik ve isteksizlik olduğunu belirtmişlerdir. Öğretmen adaylarından sadece bir kaçı, öğrencinin matematiksel işlem bilgisinde ve matematiksel bilgilerde sorun yaşadığını ifade etmiştir. İki öğretmen adayı öğrencinin matematik güçlüğü yaşıyor olabileceğini ancak bu durumun öğrencinin RAM'a yönlendirilmesiyle anlaşılabileceğini belirtmişlerdir.

Bu durumu açıklayan örnekler aşağıda sunulmuştur.

Ö.A.31. Matematik güçlüğü yaşamaktadır. Temel bilgileri tam kavrayamadığı için diğer konuları da kavramakta sıkıntı yaşamaktadır.

Ö.A.68. Batuhan'da matematik güçlügü vardır. Çünkü işlemleri yarım bırakması ve derslere ilgisiz olması bunun belirtisidir. Ayrıca da hataları tekrarlaması da bunun göstergesidir.

Video 2'de izlediğiniz öğrenciye ilişkin izleyeceğiniz yolu açıklayınız maddesine verilen yanıtlar incelendiğinde öğretmen adaylarının öğrencinin yaşadığı güçlükleri belirlemeye çalıştıkları görülmüştür. Öğrencinin yaşadığı güçlükleri, matematiksel işlem becerilerinde yaşanan sorunlar, hatalı işlem yapma, strateji geliştirememe, problem çözme becerisinde yaşanan sıkıntılar, matematiksel ifadeleri anlamama şeklinde sıralamışlardır. Öğretmen adaylarının çoğu öğrencinin yaşadığı güçlüklere ilişkin nasıl bir yol izlemesi gerektiğini bilmediklerini ifade etmişlerdir. Güçlüklerin giderilmesine yönelik yapılan önerilerde ise somutlaştrarak öğretim yapma, aile ile işbirliğinde bulunma ve destek çalışmalar yapma şeklinde belirtmişlerdir. Ancak destek çalışmalarının içeriği hakkında detaylı bilgi vermediklerini söylemek mümkündür. Bu durumu açıklayan örnekler aşağıda sunulmuştur.

Ö.A.15. Matematiksel becerilerin üzerinde durulmalı. Dört işlem becerilerinde güçlük yaşıyor. Bunun için de çeşitli yöntemler kullanılmalı...

Ö.A.17. ... Matematik kavramları yeniden öğretilmelidir. ...

Ö.A.32. Matematiksel bir dil kullanmıyor. ... Birimleri bilmiyor. ... Problemi anlamakta zorlanıyor. Problem üzerinde düşünmüyor. İ̧̧lem becerisi zayıf, nasıl işlem yapacağını bilmiyor. ... Çeşitli envanterlerle güçlük belirlenir, bir plan hazırlanıp güçlük giderilmeye çalışılır. ...

Öğretmenlerin okuma ve matematik güçlüklerinin tespitinde kullanabilecekleri en etkili yöntemin hata analizi olduğunu söylemek mümkündür (Altındağ-Kumaş, 2014). Hata analizinin öğrenci performansı ve beceri düzeyi hakkında bakış açısı kazandırabilmesi için iyi planlanmış, kapsamlı olması gerekir. Ancak okuma ve matematik güçlüğünün ve güçlüğe göre müdahale programının belirlenmesinde hata analizinin yanı sıra gözlem raporları, aile ile görüşme, meslektaş ve uzman görüşü alma, sınıf içi değerlendirme, alternatif ölçme değerlendirme yaklaşımlarından yararlanma kritik önem taşımaktadır (Bender, 2012; McLoughlin ve Lewis, 2004). Okuma ve matematik güçlüklerinin giderilmesi; doğrudan öğretimi, okuma ve matematik temel becerilerini kazandırmaya ve geliştirmeye yönelik stratejileri, eğitim ortamlarının bireysel farklılıklara ve ihtiyaçlara göre düzenlenmesi ve zenginleştirilmesini, öğrenci becerilerinin ve öğrenme ortamlarının sürekli değerlendirilmesi ve değerlendirme sonuçlarının yorumlanarak sistematik bir müdahale programının kullanıımasını kapsamaktadır. Bu kapsam doğrultusunda, öğretmen adaylarının okuma ve matematik güçlüklerinin tespitinde ve güçlüklerinin giderilmesinde izlenecek yollara ilişkin bilgi ve uygulama eksikliklerinin olduğunu söylemek mümkündür. 


\section{Sonuçlar ve Öneriler}

Bu başlık altında araştırmanın temel soruları olan; a) öğretmen adaylarının okuma ve matematik güçlüklerine ilişkin farkındalıkları ve b) öğretmen adaylarının okuma ve matematik güçlüklerine ilişkin öğretimsel bakış açıları ışı̆ında elde edilen bulgular ve bulgulara ilişkin yorumlardan elde edilen sonuçlar tartşılarak sunulmuştur.

Araştırma bulguları ve bu bulguların yorumlanması sonucunda öğretmen adaylarının okuma ve matematik güçlüklerine ilişkin genel ve göreceli bir farkındalığa sahip olduklarını söylemek mümkündür. Ancak öğretmen adaylarının yanıtları incelendiğinde, okuma ve matematik güçlüklerine ilişkin gerçek ve olgusal bilgi eksikliklerinin olduğu ve yanılgılara sahip oldukları görülmüştür. Bununla birlikte okuma ve matematik güçlükleri konusunda, bu güçlüklerin nasıl tespit edileceği ve nasıl giderileceğine ilişkin bir öngörüye ve öğretimsel bakış açısına sahip olmadıkları belirlenmiştir.

Araştırma bulguları incelendiğinde öğretmen adaylarının, okuma ve matematik güçlükleri kavramlarını açıklamada zorlandıkları söylenebilir. Öğretmen adaylarının okuma ve matematik güçlüğü yaşayan öğrencilere ilişkin sunulan durumlar ile ilgili yaptıkları değerlendirmelerden; okuma ve matematik güçlüklerinin kapsamını, kavramlarını, tanılama ölçütlerini, okuma ve matematik güçlüğü yaşayan öğrencilerle ilgili öğretimsel müdahale adına nasıl bir yol izlenmesi gerektiğini bilmedikleri görülmüştür. Bu durumu okuma ve matematik güçlüklerinin ve eğitsel müdahale yaklaşımlarına ilişkin bilgilerin lisans eğitim programında (YÖK, 1998) yer alan Illkokuma Yazma Öğretimi, Türkçe Öğretimi, Matematik Öğretimi I ve II, Özel Eğitim derslerinin içeriğinde kapsamlı bir şekilde yer almaması şeklinde açıklamak mümkündür. Bunun yanısıra, bu derslerin dışında doğrudan bu güçlüklerle ilgili içeriği olan bir derste bulunmamaktadır.

Okuma ve matematik güçlüklerinin sınıf ortamında tanılanmasında ve öğrencilere müdahale programlarının uygulanmasında iki temel ölçüt bulunmaktadır. Birincisi, sınıf öğretmenleri öğrenme ortamını gözlemleyerek, okuma ve matematik güçlüklü öğrencilerin belirlenmesinde en önemli bilgi kaynağıdır (McLoughlin ve Lewis, 2004). íkincisi ise, sınıf öğretmenleri tanılama sonuçlarını esas alarak öğrencilerin bireysel farklılıklarına göre müdahale programı geliştirmede ve uygulamada birincil rol oynamaktadır (Duffy ve Atkinson, 2001; Westwood, 2000). Bu nedenle öğretmen adaylarının sınıf öğretmeni olarak yetiştirilme sürecinde okuma ve matematik güçlüklerine yönelik bir hazırlık eğitimi almaları önemli bir durumdur (Stuart, 2000; Westwood, 2008). Araştırma bulgularının bu durumu desteklediği görülmektedir.

Okuma ve matematik güçlüğüne ilişkin Türkiye'de yapılan araştırmalar incelendiğinde bu araştrrma ve sonuçlarıyla benzer özellik taşımasa da araştırmaların odak noktasının okuma ve matematik güçlüğünün kapsamı (Olkun, Akkurt-Denizli ve Göçer-Şahin, 2015, Tatar ve Dikici, 2008), okuma ve matematik güçlüğü yaşayan öğrencilerin özelliklerinin belirlenmesi (Turgut, 2008), okuma ve matematik güçlüğünün giderilmesine yönelik uygulamalar (Akyol, Çakıroğlu ve Kuruyer, 2014; Dündar ve Akyol, 2014; Baydık, 2011; Bintaş, 2007), sınıf öğretmeni ve sınıf öğretmeni adaylarının karşılaştıkları sorunlar (Altun, Ekiz ve Odabaşı, 2011; Başar ve Göncü, 2018; Çakıroğlu ve Kuruyer, 2012; Hacısalioğlu-Karadeniz, 2013; Sezer ve Akın, 2011; Yurdakal, 2014) olduğunu söylemek mümkündür. Araştırmaların daha çok okuma ve matematik güçlüğü yaşayan öğrencilerin güçlüklerinin tanılanma ve giderilmesinde izlenecek standart yollar ile sınıf öğretmeni ve adaylarının bu süreçte sahip olması gereken bakış açısı ve mesleki yeterlilikler hakkında yapılmasının bu konuda daha faydalı olabileceği söylenebilir.

Eğitim sistemimizin okuma ve matematik alanlarında güçlük yaşayan öğrencileri tanılama çalışmalarının yanısıra temel eğitim sürecinde kritik önem taşıyan sınıf öğretmenlerine yönelik bir bakış açısı geliştirmesi ve sistemin bu bakış açısıyla yeniden yapılandııılmasının önem taşıdığını söylemek mümkündür. Çünkü ilkokullarda okuma ve matematik güçlüğünün tanılanmasına ve müdahale çalışmalarına yönelik standart bir uygulamanın olmaması ve öğretmenlerin de bu konuda kişisel gelişimlerinin dışında mesleki formasyonlarının eksikliği önemli bir sorun teşkil etmektedir. Bu araştırma kapsamında çalışma grubunda yer alan sınıf öğretmeni sayısı (73) bir sınırlılık olarak göz önünde bulundurulmalıdır. Daha sonra yapılacak çalışmalar için farklı özelliklerde ve daha büyük çalışma gruplarıyla sınıf öğretmenlerinin okuma ve matematik güçlüğüne ilişkin pedagojik farkındalıklarının ve öğretimsel bakış açılarının değerlendirilmesi önerilmektedir. İleri araştırmalarda okuma ve matematik güçlüğü olan öğrencilerin, ailelerinin, sınıf öğretmenlerinin ve paydaşlarının görüşlerine ve deneyimlerine odaklanılmasının önemli olduğu düşünülmektedir. Ayrıca sınıf öğretmeni adaylarının okuma ve matematik güçlüğüne ilişkin pedagojik farkındalık ve öğretimsel bakış açılarının niceliksel ve niteliksel olarak desenlenecek araştrmalara da yer verilebilir. Özellikle Sınıf Öğretmenliği lisans programının güncellenmesi, programa okuma ve matematik güçlükleriyle ilgili derslerin konulması, ya da ilgili derslerin içeriklerinin bu açıdan yeniden düzenlenmesinin önemli olduğu söylenebilir. Bununla birlikte ilkokullarda okuma ve matematik güçlükleriyle ilgili tanılama ve müdahale sistemlerinin geliştirilmesi, alan uzmanlarının destek öğretmen olarak okullarda görev yapması, öğretmen adaylarının geliştirilecek tanılama ve müdahale programlarıyla deneyim kazanmasına ve destek öğretmenlerle işbirliği içinde çalışmasına olanak tanınmalıdır. Ileri araştırmalarda sınıf öğretmenlerinin okuma ve matematik güçlüklerine ilişkin pedagojik farkındalıklarına ve öğretimsel bakış açılarına odaklanılmasının önemli olduğu düşünülmektedir.

| Kastamonu Eğitim Dergisi, 27(4), 2019| 


\section{Kaynakça}

Akyol, H. (2005). Türkçe ilk okuma yazma öğretimi. Ankara: Pegem.

Akyol, H., Çakıroğlu, A., \& Kuruyer, H. G. (2014). A study on the development of reading skills of the students having difficulty in reading: Enrichment reading program. International Electronic Journal of Elementary Education, 6(2), 199-212.

Akyol, H., \& Yıldız, M. (2013). Okuma uzmanlığı ve okuma uzmanı yetiştirilmesine yönelik bir program önerisi. Okuma Yazma Eğitimi Araştirmaları, 1(1), 1-8.

Alttndağ-Kumaş, Ö. (2014). Öğrenme güçlüğü olan ve olmayan öğrencilerin toplama ve çıkarma işlemlerindeki performansları. Yayımlanmamış Yüksek Lisans Tezi. Ankara Üniversitesi, Eğitim Bilimleri Enstitüsü, Ankara.

Altun, M. (2014). Eğitim fakülteleri ve sınıf öğretmenleri için matematik öğretimi. Ankara: Pegem.

Altun, T., \& Uzuner, F. G. (2016). Sınıf öğretmenlerinin özel öğrenme güçlüğü olan öğrencilerin eğitimine yönelik görüşleri. The Journal of Academic Social Science Studies, 44, 33-49.

Altun, T., Ekiz, D., \& Odabaşı, M. (2011). Sınıf öğretmenlerinin sınıflarında karşılaştıkları okuma güçlüklerine ilişkin nitel bir araştırma. Dicle Üniversitesi Ziya Gökalp Eğitim Fakültesi Dergisi, 17, 80-101. http://www.zgefdergi.com/Makaleler/718148595 1706 Altun-Ekiz-Odabasi.pdf adresinden 31.08.2015 adresinden edinilmiştir.

Antoniou, F., \& Souvignier, E. (2007). Strategy instruction in reading comprehension: An intervention study for students with learning disabilities. Learning Disabilities: A Contemporary Journal, 5(1), 41-57.

Başar, M., \& Göncü, A. (2018). Sınıf öğretmenlerinin öğrenme güçlüğüyle ilgili kavram yanılgılarının giderilmesi ve öğretmen görüşlerinin değerlendirilmesi. Hacettepe Üniversitesi Eğitim Fakültesi Dergisi, 33(1), 185-206.

Balıkçı, S., Ö. (2017). Özel öğrenme güçlüğü olan bireyler için akademik destek. Macid Ayhan Melekoğlu, Uğur Sak (Ed). Öğrenme güçlüğü ve özel yetenek (s. 78-91). Ankara: Pegem.

Baydık, B. (2011). Okuma güçlüğü olan öğrencilerin üstbilişsel okuma stratejilerini kullanımı ve öğretmenlerin okuduğunu anlama öğretim uygulamalarının incelenmesi. Eğitim ve Bilim, 36(162), 301-319. http://egitimvebilim.ted.org.tr/index.php/EB/article/viewFile/1354/330 adresinden edinilmiştir.

Baydık, B. (2014). Öğrenme güçlüğü yaşayan çocukların gelişim özellikleri. Sunay Yıldırım Doğru (Ed). Öğrenme güçlükleri (s.6778). Ankara: Eğiten Kitap.

Baykul, Y. (2009). illköğretimde matematik öğretimi. Ankara: Pegem.

Bintaş, J. (2007). Matematikte öğrenme güçlüğü olan öğrenciler için matematik eğitimi. e-Journal of New World Sciences Academy, 2(4), 439-450. http://www.newwsa.com/download/gecici makale dosvalari/NWSA-53-146-3.pdf adresinden 31.08.2015 adresinden edinilmiştir.

Bender, W. N. (2012). Öğrenme güçlüğü olan bireyler ve eğitimleri. Hakan Sarı (Çev. Ed.). Ankara: Nobel.

Bonds, C.W. \& Bonds, L.G. (1992). Metacognition: developing independence in learning, Clearing House, 66(1), 56-59.

Butterworth, B. (2005). Developmental dyscalculia. In J.I.D. Campell, (Ed.). Handbook of mathematical cognition (455-468). Newyork, NY: Taylor \& Francis.

Butterworth, B., Varma, S., \& Laurillard, D. (2011). Dyscalculia: from brain to education. Science, 332, 1049-1053. doi: 10.1126/ science.1201536

Bryant, D. P., Bryant, B. R., Gersten, R., Scammacca, N., \& Chavez, M. M. (2008). Mathematics intervention for first-and second-grade students with mathematics difficulties: The effects of tier 2 intervention delivered as booster lessons. Remedial and special education, 29(1), 20-32.

Calhoon, B., M. (2005). Effects of a peer-mediatedphonologicalskillandreadingcomprehension program on reading skill acquisition for middle school students with reading disabilities. Journal of Learning Disabilities. 38(5), 424-433.

Cohen, L., Manion , L., \& Marison, K. (2007). Research methods in education. Newyork: Routhledge.

Çakıroğlu, A., \& Kuruyer, H. G. (2012, February). First grade elementary school student's family involvement in the process of reading and writing skills acquisition.World Congress Education Sciences, Barcelona, Spain.

Deniz, M. E., Yorgancı, Z., \& Özyeşil, Z. (2009). Öğrenme güçlüğü görülen çocukların sürekli kaygı ve depresyon düzeylerinin incelenmesi üzerine bir araştırma. Illköğretim Online, 8(3), 694-708.

Dirks, E., Spyer, G., van Lieshout, E. C., \& de Sonneville, L. (2008). Prevalence of combined reading and arithmetic disabilities. Journal of Learning Disabilities, 41, 460-473.

DSM-IV (2000). Diagnosticand Statistical Manual of MentalDisorders, Fourth Edition, Text Revision (DSM-IV-TR). American Psychiatric Association.

DSM-V (2013). Diagnostical and statistical manual of mental disorders. Fifth Edition. American Psychiatric Association.

Duffy, A. M., \& Atkinson, T. S. (2001). Learning to teach struggling (and non-struggling) elementary school readers: An analysis of preservice teachers' knowledges. Literacy Research and Instruction, 41(1), 83-102. 
Dündar, H. \& Akyol, H. (2014). Okuma ve anlama problemlerinin tespiti ve giderilmesine ilişkin örnek olay çalışması. Eğitim ve Bilim, 39(171), 361-377. http://egitimvebilim.ted.org.tr/index.php/EB/article/download/1991/633 adresinden edinilmiştir.

Erden, G. (2006). Özgül öğrenme güçlüğü (ÖÖG) bataryası formu kurs notları.

Fuchs, L. S., Seethaler, P. M., Powell, S. R., Fuchs, D., Hamlett, C. L., \& Fletcher, J. M. (2008). Effects of preventative tutoring on the mathematical problem solving of third-grade students with math and reading difficulties. Exceptional children, 74(2), 155-173.

Fuchs, L. S., Powell, S. R., Seethaler, P. M., Cirino, P. T., Fletcher, J. M., Fuchs, D., \& Hamlett, C. L. (2010). The effects of strategic counting instruction, with and without deliberate practice, on number combination skill among students with mathematics difficulties. Learning and individual differences, 20(2), 89-100.

Garner, B. D. (2008). Postsecondary education success: Stories of three students with learning disabilities. TEACHING Exceptional Children Plus, 4(4), 2-10. http://files.eric.ed.gov/fulltext/EJ967484.pdf adresinden edinilmiştir.

Geary, D. C. (1993). Mathematical disabilities: Cognitive, neuropsychological and genetic components. Psychological Bulletin, 114, 345-362.

Gersten, R., Fuchs, L. S., Williams, J. P., \& Baker, S. (2001). Teaching reading comprehension strategies to students with learning disabilities: A review of research. Review of educational research, 71(2), 279-320.

Gifford, S., \& Rockliffe, F. (2008). Insearch of dyscalculia. Proceedings of the British Society for Research into Learning Mathematics, 28(1), 21-27.

Glenberg, A. M. (2011). How reading comprehension is embodiedand why that matters. International Electronic Journal of Elementary Education, 4(1), 5-18.

Görgün, B. (2017). Özel öğrenme güçlüğünün tanılanması. Macid Ayhan Melekoğlu, Uğur Sak. Öğrenme güçlüğü ve özel yetenek (s. 54-76). Ankara: Pegem.

Grünke, M., \& Morrison Cavendish, W. (2016). Learning disabilities around the globe: Making sense of the heterogeneity of the different viewpoints. Learning Disabilities: A Contemporary Journal, 14(1), 1-8.

Güneş, F. (2003). Okuma-yazma öğretiminde cümlenin önemi. TÜBAR, 13, 38-48. http://www.tubar.com.tr/TUBAR\%20DOSYA/ pdf/2003BAHAR/4firdevs\%20gunes.pdf adresinden edinilmiştir.

Güneş, F. (2013). Türkçe öğretimi yaklaşım ve modeller. Ankara: Pegem.

Hacisalioğlu-Karadeniz, M. (2013). Diskalkuli yaşayan öğrencilere ilişkin öğretmen görüşlerinin değerlendirilmesi. E-Journal of New World Sciences Academy, 8(2). 193-208. http://www.newwsa.com/download/gecici makale dosyalari/NWSA-71323138-10.pdf adresinden 31.08.2015 adresinden edinilmiştir.

Haylock, D. \& Cockburn, A. (2014). Küçük çocuklar için matematiği anlama. Zuhal Yılmaz (Çev. Ed.). Ankara: Nobel.

İşeri, E. \& Akın-Sarı, B. (2011). Çocukta bilişsel gelişim ve bozukluklar: Zeka geriliği ve öğrenme bozuklukları. S. Karakaş. (Ed.). Kognitif nörobilimler. Ankara: MN Medikal \& Nobel Tıp Kitap Sarayı.

Jaya, N., \& Geetha, T. (2009). Primary school teachers' skills to help dyscalculic children. Delhi: G. Print Process.

Jitendra, A. K., Hoppes, M. K. ve Xin, Y. P. (2000), Enhancing Main Idea Comprehension for Students with Learning Problems: The Role of a Summarization Strategy and Self-Monitoring Instruction, The Journal of Special Education, 30(3), $127-139$.

Jonassen, D., Grabowski, B. (1993). Handbook of individual differences, learning, and instruction. New York: Routledge.

Kamhi, A. \& Catts, H. (2008). The language basis of reading: Implications of classification and treatment of children with reading disabilities. In Bulter, K. \& Silliman, E. (Eds.) Speaking, reading, and writing in children with language and learning disabilities: New paradigms in research and practice (pp. 45-72). Mahwah: Lawrence Erlbaum Associates.

Karasu, H. P., Girgin, Ü., \& Uzuner, Y. (2011). Okuma becerilerini değerlendirmede formel olmayan okuma envanterlerinin kullanımı. Eğitim Teknolojisi Kuram ve Uygulama, 1(1), 108-124.

Kirk, S., Gaalgher, J., \& Coleman, M., R. (2017). Özel gereksinimli çocukların eğitimi. Salih Rakap (Çev. Ed.). Ankara: Nobel.

Kuruyer, H., G. (2014). Zenginleştirilmiş okuma programının okuma güçlüğü olan öğrencilerin bilişsel süreç ve nöral yapılarına etkisi. Yayımlanmamış Doktora Tezi. Gazi Üniversitesi, Eğitim Bilimleri Enstitüsü, Ankara.

Kuruyer, H. G., \& Çakıroğlu, A. (2017). Sınıf öğretmenlerinin özel öğrenme güçlüğü olan öğrencilerin eğitsel değerlendirme ve eğitimsel müdahale sürecinde görüş ve uygulamaları. Turkish Studies, 12(28), 539-555.

Landerl, K., Bevan, A., \& Butterworth, B. (2004). Developmental dyscalculia and basic numerical capacities: A study of 8-9-year-old students. Cognition, 93(2), 99-125.

Landerl, K., Fussenegger, B., Moll, K., \& Willburger, E. (2009). Dyslexia and dyscalculia: Two learning disorders with different cognitive profiles. Journal of Experimental Child Psychology, 103, 309-324.

Melekoğlu, M. A. (2017). Özel öğrenme güçlüğünün nedenleri ve özellikleri. Macid Ayhan Melekoğlu, Uğur Sak. Öğrenme güçlüğü ve özel yetenek (s. 24-52). Ankara: Pegem.

Milli Eğitim Bakanlığı (MEB). 2018. İlkokul ve Ortaokul Matematik Dersi (1-8. Sınıflar) Öğretim Programı ve Kılavuzu. Ankara: MEB. Miles, M. B., \& Huberman, A. M. (1994). Qualitative data analysis: An expanded sourcebook. Sage. 
Morrison, J. (2016). DSM-5'i kolaylaştıran 'Klinisyenler için tanı rehberi'. Muzaffer Şahin (Çev Ed.). Ankara: Nobel.

Moddy, M., Kennedy, S. M., \& Brady, S. (1997) Speech perception deficits in poor readers: Auditory processing or phonological coding. Journal of Experimental Child Psychology 64, 199-231.

National Joint Committee on Learning Disabilities. (2000). Professional development for teachers. Learning Disability Quarterly, 23, 2-6.

Olkun, S. (2014). Öğrenme güçlüğü yaşayan çocukların gelişim özellikleri. Sunay Yıldırım Doğru (Ed). Matematik öğrenme güçlükleri/diskalkuli (s.211-225). Ankara: Eğiten Kitap.

Olkun, S., Akkurt-Denizli, Z. \& Göçer-Şahin, S. (2015). Öğrencilerin diskalkuliye yatkınlıklarının belirlenmesinde nokta sayılama ve sayısal karşılaşttrma becerileri. Turkish International Journal of Special Education and Guidance \& Counseling, 3(2), 62-71. http://www.iojpe.org/ojs/index.php/IJSEG/article/viewFile/400/477 adresinden edinilmiştir.

Özdemir, M., S. (2008). Sınıf öğretmeni adaylarının öğretim sürecine ilişkin öz-yeterlik inançlarının çeşitli değişkenler açısından incelenmesi. Kuram ve Uygulamada Eğitim Yönetimi, 54, 277-306. https://www.pegem.net/dosyalar/dokuman/9899-20110603103235-06.-ozdemir.pdf adresinden 28.28.2015 adresinden edinilmiştir.

Özel Eğitim ve Rehberlik Hizmetleri Genel Müdürlüğü Bilim ve Sanat Merkezleri Öğrenci Seçme Sınavı. (2015). Ankara: MEB.

Özkardeş-Güngörmüş, O. (2013). Türkiye'de özel öğrenme güçlüğüne ilişkin yapılan araşttrmaların betimsel analizi. Boğaziçi Üniversitesi Eğitim Dergisi, 30(2), 123-153.

Özkut, Ç. (2011). Illköğretimdeki öğrencilerin sınıflara göre matematik beceri düzeylerinin belirlenmesi. Yayımlanmamış Yüksek Lisans Tezi. Dokuz Eylül Üniversitesi Eğitim Bilimleri Enstitüsü, İzmir.

Özyürek, M. (2015). Öğrenme güçlüğü olan çocukların eğitimi. Gönül Akçamete (Ed.). Genel eğitim okullarında özel gereksinimi olan öğrenciler ve özel eğitim (s. 315-336). Ankara: Kök.

Piazza, M., Facoetti, A., Trussardi, A. N., Berteletti, I., Conte, S., Lucangeli, D., Dehaene, S., \& Zorzi, M. (2010). Developmental trajectory of number acuity reveals a severe impairment in developmental dyscalculia. Cognition, 116(1), 33-41.

Re, A. M., Pedron, M., Tressoldi, P. E., \& Lucangeli, D. (2014). Response to specific training for students with different levels of mathematical difficulties. Exceptional Children, 80(3), 337-352.

Reid, R., Lienemann, T. O., \& Hagaman, J. L. (2013). Strategy instruction for students with learning disabilities. Guilford Publications. Santrock, W., J. (2016). Yaşam boyu gelişim: Gelişim psikolojisi. Galip Yüksel (Çev. Ed.). Ankara: Nobel.

Sezer, S. \& Akın, A. (2011). 6-14 yaş arası öğrencilerde görülen matematik öğrenme bozukluğuna ilişkin öğretmen görüşleri. Illköğretim Online, 10(2), 757-775.

Silver, H. C., Ruff, M.R., Iverson, L. G., Barth, T. J., Broshek, K. D., Bush, S. S., Koffler, P.S., Reynolds, R. C. (2008). Learning disabilities: The need for neuropsychological evaluation. Archives of Clinical Neuropsychology 23(2), 217-219.

Singh, P., Y., \& Agarwal, A. (2011). Teaching addition to children with dyscalculia through CAI. Indian Streams Research Journal, 1(1), 1-7.

Snowling, M. (2012). Early identification and interventions for dyslexia: A contemporary view. Journal of Research in Special Educational Needs, 13(1), 7-14. doi: 10.1111/j.1471-3802.2012.01262.x

Swanson, H. L., Moran, A. S., Bocian, K., Lussier, C., \& Zheng, X. (2013). Generative strategies, working memory, and word problem solving accuracy in children at risk for math disabilities. Learning Disability Quarterly, 36(4), 203-214.

Swanson, H. L., Lussier, C., \& Orosco, M. (2013). Effects of cognitive strategy interventions and cognitive moderators on word problem solving in children at risk for problem solving difficulties. Learning Disabilities Research \& Practice, 28(4), $170-183$.

Swanson, H. L., Orosco, M. J., \& Lussier, C. M. (2014). The effects of mathematics strategy instruction for children with serious problem-solving difficulties. Exceptional Children, 80(2), 149-168.

Swanson, H. L., Lussier, C. M., \& Orosco, M. J. (2015). Cognitive strategies, working memory, and growth in word problem solving in children with math difficulties. Journal of Learning Disabilities, 48(4), 339-358.

Schunk, D. H., (2010). Learning Theories: an Educational Perspective. M. Şahin, (Çev. Ed.). Ankara: Ankara.

Tatar, E. \& Dikici, R. (2008). Matematik eğitiminde öğrenme güçlükleri. Mustafa Kemal Üniversitesi Sosyal Bilimler Enstitüsü Dergisi, 5(9), 183-193.

Temur, T. (2006). İlköğretim 4 ve 5. sınıf öğrencilerinin yazı dilindeki kelime hazinelerinin bazı değişkenler açısından incelenmesi. Yayımlanmamış Doktora Tezi. Gazi Üniversitesi, Eğitim Bilimler Enstitüsü, Ankara.

Torgessen, K., J. (2002). The Prevention of reading difficulties. Journal of School Psychology, 40(1). 7-26. doi:10.1016/S00224405(01)00092-9

Tuğrul Kalaç, E (2015). Öğrenme güçlüğü ve matematik. Macid Ayhan Melekoğlu \& Orhan Çakıroğlu (Ed.). Özel öğrenme güçlüğü olan çocuklar (s.245-280). Ankara: Vize.

Turgut, S. (2008). Özgül öğrenme güçlüğünde nöropsikolojik profil. Yayımlanmamış Yüksek Lisans Tezi. Sosyal Bilimler Enstitüsü, Hacettepe Üniversitesi, Ankara. 
Uberti, H. Z., Mastropieri, M. A., \& Scruggs, T. E. (2004). Check it off: Individualizing a math algorithm for students with disabilities via self-monitoring checklists. Intervention in School and Clinic, 39(5), 269-275.

Uegaki. C., Jorish, S. (2016). Suki'nin Kimonosu. Gökçe Gökçeer (Çev. Ed). İstanbul: MEAV.

Van de Walle, K., \& Karp, K. S. Bay-Williams (2013). Elementary and middle school mathematics: Teaching developmentally.

Williams, A. (2013). A teacher'sperspective of dyscalculia: Who counts? An interdisciplinary overview. Australian Journal of Learning Difficulties, 18(1), 1-16. doi:10.1080/19404158.2012.727840

Westwood, P. (2008). What teachers need to know about learning difficulties. Aust Council for Ed Research.

Woodcock, S. (2013). Trainee teachers' attitudes towards students with specific learning disabilities. Australian Journal of Teacher Education, 38(8), 16-29.

Woolfolk-Hoy, A., \& Spero, R. (2005). Changes in teacher efficacy during the early years of teaching: A comparison of four Measures. Teaching and Teacher Education, 21, 343-356.

Woolley, G. (2007). A comprehension intervention for children with reading comprehension difficulties. Australian Journal of Learning Difficulties, 12(1), 43-50. doi:10.1080/19404150709546829

Yıldırım, C. (2000). Matematiksel Düşünme. İstanbul: Remzi.

Yıldırım, K. (2010). İş birlikli öğrenme yönteminin okumaya ilişkin bazı değişkenler üzerindeki etkisi ve yönteme ilişkin öğrenci-veli görüşleri. Yayımlanmamış Doktora Tezi. Gazi Üniversitesi, Gazi Eğitim Bilimleri Enstitüsü, Ankara.

Yıldırım, A. \& Şimşek, H. (2008). Sosyal Bilimlerde Nitel Araştırma Yöntemleri. Ankara: Seçkin.

YÖK. (1998). Eğitim Fakültesi Öğretmen Yetiştirme Lisans Programları. Ankara: YÖK.

Yurdakal, H., í. (2014). illkokullarda okuma güçlüğünde yaşanan sorunlar ile eğitim uygulamalarına ilişkin öğretmen ve öğrenci görüşleri. Yayımlanmamış yüksek lisans tezi. Pamukkale Üniversitesi Eğitim Bilimleri Enstitüsü, Pamukkale. 